\title{
EUKARYOTIC BIODIVERSITY IN MIXED PEAT ECOSYSTEMS IN SARAWAK, MALAYSIA
}

\author{
SITI RAMLAH AHMAD ALI*; MOHD NOOR MAT ISA**; SAKINAH SAFARI*; MOHD SHAWAL

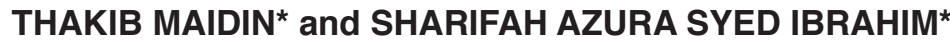

\begin{abstract}
Eukaryotes are ubiquitous and play critical roles in food web dynamics, global carbon and nutrient cycle. Possessing multiple nutritional modes, eukaryotes play key roles as producers, decomposers, parasites, and predators. Little is known about the composition and diversity of eukaryotes in the different tropical peat ecosystems and how land-use change affect them. In this study, next generation sequencing was used for sequencing within the $18 \mathrm{~S} r \mathrm{DNA}$ gene to analyse the differences in the diversity and relative abundance of eukaryotes types. The finding indicated, in the dry month of April 2012, the operational taxonomic unit for eukaryotic community for peatland at Maludam National Park was low (986), high for logged over peatland Cermat Ceria (1853) and 7 years old oil palm plantation (1677) at Durafarm, Sri Aman, Sarawak and decreased to 865 for 11 years old oil palm at Naman, Sibu, Sarawak, Malaysia. Similarly, the $\alpha$-diversity of eukaryotic community indicated species per sample ID at Maludam was low (65), high (450) for loggedover peatland and Durafarm (400) and Naman (200). Total phyla was highest, 28 for oil palm plantation at Durafarm, 27 for logged-over peatland, 23 for Maludam and 20 for Naman. The taxonomic composition of eukaryotic community indicated the population at the peatlands comprised mainly of fungi and other unclassified eukaryotes. While under the matured oil palm plantations, the predominant eukaryotic kingdom was fungi. The common fungal phyla for all peat ecosystems were Ascomycota, Basidiomycota, Fungi incertae sedis and Chytridiomycota. Ustilaginomycota being dicot parasitic fungi, was found in the peatlands at Maludam and Cermat Ceria but absent in oil palm plantations. Blastocladiomycota was absent in Maludam National Park but present in all other peat ecosystems. While, Glomeromycota and Neocallimastigomycota were present in logged-over peatland. The fungal population increased in the oil palm cultivated areas because of the absence of water logged area, drainage system for water management, presence of abundant organic biomass, high rainfall, soil acidity and soil moisture content. On the contrary, the minor predatory, autothropic and parasitic Alveolata, Nuclearidae and Fonticula, Rhizaria, Stramenopiles and Amoebozoa decreased with drainage and cultivation of oil palm and reduction of aquatic flora and fauna. The impacts of human activities such as construction of drainage system, logging and cultivation of oil palm resulted in obvious increase in the eukaryotic biodiversity due to abundant organic biomass and reduction in water logged peat. As the oil palm reached the aged of 11 year the eukaryotic biodiversity declined, probably due to peat compaction and reduction of decaying organic matters.
\end{abstract}

Keywords: eukaryotes, biodiversity, mixed peat, ecosystems.

Date received: 23 October 2017; Sent for revision: 30 October 2017; Received in final form: 12 January 2018; Accepted: 2 February 2018.

\section{INTRODUCTION}

Malaysian Palm Oil Board, 6 Persiaran Institusi, Bandar Baru Bangi, 43000 Kajang, Selangor, Malaysia. E-mail: drctramlah@gmail.com

** Malaysia Genome Institute, Jalan Bangi, 43000 Kajang, Selangor, Malaysia.
Tropical peat ecosystems respiration consists of heterotrophic and autotrophic respiration. The former is a process assisted by degrading microbes in the peat while autotrophic respiration is a process of respiration from plants and roots (Page et al., 2010). 
Peat swamp forest has turned into a carbon source for economic development purposes, such as intensive logging, drainage and conversion to agricultural crop (Riley, 2011; Takashi et al., 2014; Yu, 2012). Peatland is an important area for global carbon cycle due to the large amount of carbon that can be stored and released to the atmosphere (Yu, 2012; Takashi et al., 2014). This contributed to the beta diversity with their groups of specialised and unique plants and animals (Mac Nally et al., 2004) as well as in global climate regulation of methane $\left(\mathrm{CH}_{4}\right)$ emissions (Couwenberg and Fritz, 2012; Kip et al., 2010).

Peatland management (e.g. drainage) was shown to change the physical and chemical properties of peatland as well as the vegetation communities, which, in turn, alters the microbial environment in peatland (Laine et al., 1995). The physical, chemical factors and land-use change will affect the structure of microbial communities in a habitat (Nacke et al., 2011). In addition, the diverse litter input probably also has a great impact on the microbial community structure (Strakova et al., 2012) and soil types (Fierer et al., 2011) in the peatland. Recent study also suggested that local environmental conditions may be the determining factor for microbial community composition rather than geographical factor (Andersen et al., 2013).

Fungi are important decomposers in peatland and have received the most attention based on previous findings (Thormann, 2011; Myers et al., 2012). Fungi play key roles in the environment, with particular importance in nutrient cycling, modulation of plant growth and overall ecosystem function and stability (Taylor and Sinsabaugh, 2014; Van Der Heijden et al., 2008). Estimates of global fungal species richness are in the millions (Taylor et al., 2014), while less than $2 \%$ have been formally described (Taylor et al., 2016). Long-term elevated $\mathrm{CO}_{2}$ significantly decreased overall relative abundance of Ascomycota, but increased relative abundance of Basidiomycota ( $\mathrm{Tu}$ et al., 2015). However, the Basidiomycetous fungi activities are reduced due to the anoxic upper layers in different types of peatland (Winsborough and Basiliko, 2010).

For prediction of fungal community in an ecosytem, Illumina protocols with specially designed ITS primers, ITS1-F to ITS2 amplicon length of 530 $\mathrm{bp}$, revealed that it strongly underrepresented the fungal community (Taylor et al., 2016). ITS1-F also has mismatches with various fungi (Tedersoo et al., 2015). The newer primer FITS9 (Ihrmark et al., 2012) is a strong match to plants, while the primer BITS was not designed to exclude non-fungal lineages (Bokulich and Mills, 2013). Next generation sequencing has gained increasing attention as a novel tool for studying microbial diversity and allow us to better understand the microbial community structure (Yuanyuan et al., 2014).
The Eukarya profiles in Artic soil microbiota were dominated by $18 \mathrm{~S}$ rRNA fragments assigned to plants (Viridiplantae), primarily mosses. Other large taxa were the Metazoa, Alveolata, and Rhizaria, all of which decreased with depth (Alexander et al., 2014). A revised classification of eukaryotes (Adl et al., 2012) recognises five super groups namely, i. Archaeplastida (or Primoplantae), land plants, green algae, red algae, and glaucophytes, ii. SAR super group Stramenopiles (brown algae, diatoms, etc.), Alveolata and Rhizaria (Foraminifera, Radiolaria, and various other amoeboid protozoa), iii. Excavata which are various flagellate protozoa, iv. Amoebozoa which most lobose amoeboids and slime molds and v. Opisthokonta which include animals, fungi, choanoflagellates, etc. (Fierer et al., 2007). They account for $11 \%$ of the cellular biomass in the soil community (Urich et al., 2008). Within eukaryotes, Holozoa (animals) and Holomycota (fungi) are more closely related to each other than either is to plants, since these Opisthokonts have fusion of carbamoyl phosphate synthetase, dihydrorotase and aspartate carbamoyl transferase that is not present in plants, while plants have fusion of thymidylate synthase and dihydrofolate reductase not present in the Opisthokonts (Torruella et al., 2012). These animals and fungi are also more closely related to amoebas than they are to plants, and plants are more closely related to the SAR super group of protists than they are to animals or fungi. The Opisthokonts include the most well studied kingdoms the metazoans and fungi as well as unicellular lineages the Nucleariids, Fonticula, Filastereans, Ichthyosporeans, Corallochytrium, and Choanoflagellates (Del Campo and Ruiz-Trillo, 2013).

Although eukaryotes are major players in soil fertility and strongly influence the prokaryotic community structure, their diversity and abundance has received comparably little attention in molecular studies. Knowledge on how logging and conversion of peatlands for cultivation of oil palm affect the eukaryotic biodiversity is lacking. In this study, the 454-pyrosequencing of the $18 \mathrm{~S}$ rRNA marker was used to analyse the diversity and community structure of eukaryotes in tropical peatlands at Maludam National Park, secondary logged-over peatland at Cermat Ceria and oil palm aged 7 years at Durafarm, Sri Aman and 11 years at Naman in Betong, Sarawak, Malaysia.

\section{MATERIALS AND METHODS}

\section{Peat Sampling}

Peat samples was taken in April 2012 from four different sites, namely at tropical primary peatland 
Maludam National Park and secondary loggedover peatland at Cermat Ceria, mature oil palm aged 7 and 11 years old at Durafarm and Naman, respectively, as shown in Figure 1. For each site, 10 different GPS points and four different depths (top soil, midway between topsoil and water table, water table and below water table) were determined for sampling. In this study, the top soil was used to analyse the effect of human activities in the conversion of tropical peatland to oil palm on the eukaryotic biodiversity. The central point for the 10 sampling spots at Maludam National Park, Cermat Ceria, Durafaram and Naman was $1^{\circ} 37^{\prime} 45.4116 \mathrm{~N}$ and $111^{\circ} 2^{\prime} 23.5644 \mathrm{E}, 1^{\circ} 23^{\prime} 56.4 \mathrm{~N}$ and $111^{\circ} 24^{\prime} 21.6$ $\mathrm{E}, 1^{\circ} 23^{\prime} 50.3808 \mathrm{~N}$ and $111^{\circ} 24^{\prime} 49.6476 \mathrm{E}$, and $1^{\circ} 37^{\prime}$ $45.4116 \mathrm{~N}$ and $111^{\circ} 2^{\prime} 23.5644 \mathrm{E}$, respectively.

\section{Experiment Overview}

Metagenomics DNA for the peat samples were PCR amplified using specific 18S rRNA phylogenetic markers for analysis on the eukaryotic biodiversity. Amplified products were purified, quantified and quality checked prior to 454 Amplicon library preparation procedures. Amplicons were then sequenced using 454 FLX machine and data were analysed using QIME (Quantitative Insights into Microbial Ecology) pipeline (Caporaso et al., 2010).

\section{DNA Extraction}

GeneMATRIX soil DNA purification kit (Eurx Ltd, Gdansk, Poland) was used for total DNA extractionfrom peat samples. The amountand quality of DNA were measured using a nanophotometerTM P360 (Implen GmbH, Germany) with minimum concentration and purity of $10 \mathrm{ng} \mu \mathrm{l}^{-1}$ and $\mathrm{OD}_{260} /{ }_{280}$ of 1.8 , respectively. The extracted DNA was stored at $-20^{\circ} \mathrm{C}$ in a freezer.

\section{PCR Amplification and Purification}

Twenty-five microlitre of PCR reaction mixture was prepared using FastStart high fidelity PCR System (Roche). The mixture contained 2.0 to $5.0 \mu \mathrm{l}$

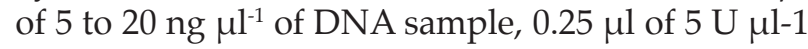
FastStart HiFi polymerase, $1.0 \mu \mathrm{l}$ of $10 \mu \mathrm{M}$ reverse primer, $1.0 \mu \mathrm{l}$ of $10 \mu \mathrm{M}$ forward primer, $200 \mathrm{ng}$ of template, $1.0 \mu \mathrm{l}$ of DMSO, $0.5 \mu \mathrm{l}$ of $10 \mathrm{mM}$ each of dNTP mix, $2.5 \mu$ l of 10 X FastStart high fidelity buffer containing $\mathrm{MgCl}_{2}$ and 13.75 to $16.75 \mu \mathrm{l}$ of nuclease free water. The Multiplex Identifier (MID) fusion

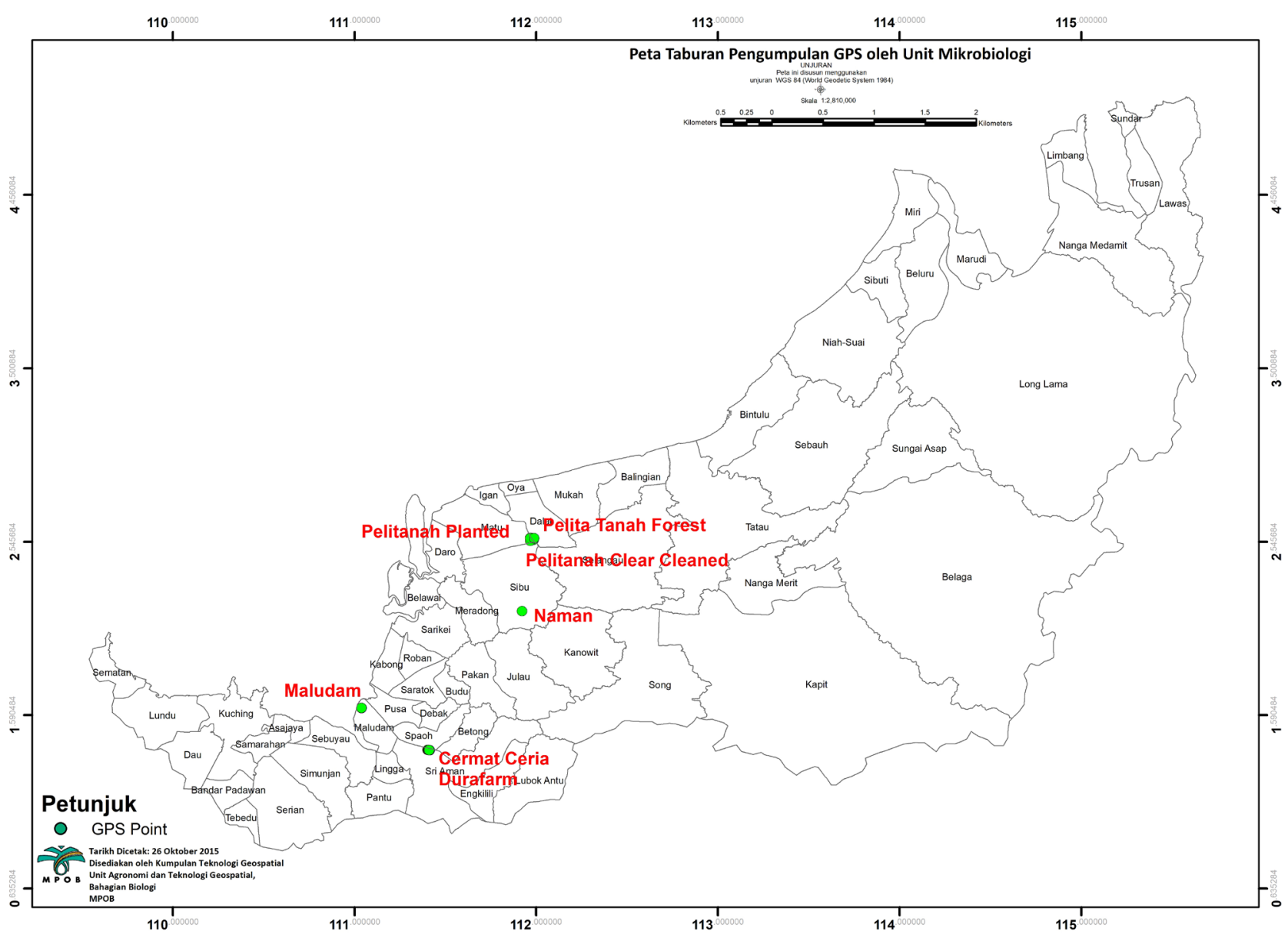

Figure 1. Map showing the sites of sampling for peat in Sarawak, Malaysia. 
primer pair, EF4 (GGAAGGGRTGTATTTATTAG) and fung5 (GGCCTTGGTCCTGAAAATG) (Smit et al., 1999) amplifies a small, 550-bp fragment. The polymerase chain reaction $(\mathrm{PCR})$ reaction begun with template denaturation at $95^{\circ} \mathrm{C}$ for $5 \mathrm{~min}$, followed by 25 cycles of template denaturation at $95^{\circ} \mathrm{C}$ for $1 \mathrm{~min}$, primer annealing at $63^{\circ} \mathrm{C}$ for $1 \mathrm{~min}$ and extension at $72^{\circ} \mathrm{C}$ for $1 \mathrm{~min}$. Final extension was performed at $72^{\circ} \mathrm{C}$ for $5 \mathrm{~min}$. A negative control reaction without template DNA was carried out under the same conditions.

\section{Amplicon Purification and Quantification}

Purification was done according to Beckman Coulter, Cat. No. A63882. A volume of $72 \mu \mathrm{l}$ of AMPure bead was added into 20 tubes labelled according to the samples. DNA template: nucleasefree water (NFW) were added in a ratio of 1.6:1. The tubes were vortex and incubated at room temperature (RT) for $10 \mathrm{~min}$, then placed onto magnetic particle collector (MPC) and incubated for $5 \mathrm{~min}$ at RT, until the supernatant was clear. The supernatant was removed without disturbing the beads. Two hundred and fifty $\mu \mathrm{l}$ of $70 \%$ freshly prepared ethanol was added into each tube and vortex. The tubes were placed onto MPC until the supernatant became clear. Then, supernatant was removed without disturbing the beads. Ethanol was removed and the lid was opened to air-dry the excess ethanol. Fifteen $\mu \mathrm{l}$ NFW (heated on $65^{\circ} \mathrm{C}$ heat block) was added into the tubes then vortex. The tubes were placed onto MPC for 2 min until the supernatant (purified amplicon) was cleared. The purified amplicons were transferred into new tubes labelled accordingly and were ready for quantification using QuantiFluor (Promega, USA).

The low DNA mass ladder and amplicons were analysed with the DNA 7500 LabChip kit (Agilent Technologies) for sizing and quantification. Chips were prepared according to the instructions provided with the DNA 7500 (Agilent Technologies) and DNA 12000 LabChip kits (Agilent Technologies). The quantification was conducted using a standard curve prepared according to QuantiFluor ${ }^{\circledR} \mathrm{dsDNA}$ System (Promega Corp). The DNA standard and PicoGreen reagent was thawed. Eight $1.5 \mathrm{ml}$ tubes were labelled as 1 to 8 . The volume of $594 \mu \mathrm{l}$ 1X TE was pipetted into tube 1 and $300 \mu$ for tube 2 to 8 . A volume of 6 ul of DNA standard was transferred to tube 1 and vortex for $10 \mathrm{~s}$. Then, $300 \mu \mathrm{l}$ mixture from tube 1 was transferred to tube 2 and vortex for $10 \mathrm{~s}$, then serial dilution was continued by transferring $300 \mu \mathrm{l}$ from one tube into the next tube, vortex for $10 \mathrm{~s}$. Tube 8 or control contained no DNA. Hundred $\mu l$ of each DNA standard dilution was transferred into the wells of a 96-well fluorometer plate. The assay was done by transferring $99 \mu \mathrm{l}$ of $1 \mathrm{X}$ TE buffer into 40 wells. One $\mu$ of each purified amplicon
DNA sample was transferred into each well. The samples were mixed by pipetting up and down four times. The assay was carried out as described by the manufacturer of the Quant-iT PicoGreends DNA Assay Kit (Promega Corp). The concentration of each amplicon was calculated in molecules / $\mu \mathrm{l}$ using the following equations:

$$
\text { Molecules } / \mu \mathrm{l}=\frac{\text { Sample concentration }\left(\mathrm{ng} \mu^{-1}\right) \times 6.022 \times 10^{23}}{565.6 \times 10^{9} \times \text { amplicon length }(\mathrm{bp})}
$$

Each of the amplicon was diluted separately to 1 x 109 molecules/ $\mu \mathrm{l}$, in 1X TE buffer. One $\mu \mathrm{l}$ of 107 molecules $/ \mu \mathrm{l}$ diluted amplicons was pooled to be sequenced together, i.e. within a region of a Pico Titer Plate.

\section{Preparation of EmPCR Amplification Reagents}

The emPCR reagents box (Roche 454 Life Sciences, Branford, CT, USA) and kit components was thawed at RT, and the enzymes was kept at $-20^{\circ} \mathrm{C}$. The tubes of emPCR were vortex and heated at $55^{\circ} \mathrm{C}$ for $15 \mathrm{~min}$ to dissolve the components. The kit components (including enzymes) were spun in a bench top mini centrifuge for $10 \mathrm{~s}$. The enzyme was kept at $-20^{\circ} \mathrm{C}$ and other kit reagents at RT.

The cups of emulsion oil (Roche 454 Life Sciences, Branford, CT, USA) was installed securely in the TissueLyser (Qiagen/Retsch), using the GS FLX titanium emPCR shaker adapters (Roche 454 Life Sciences, Branford, CT, USA). The emulsion oil was shaken at $28 \mathrm{~Hz}$ for $2 \mathrm{~min}$.

Two ml of 5X mock amplification mix was diluted with $8 \mathrm{ml}$ of molecular biology grade water (MBGW). Five $\mathrm{ml}$ of the diluted mock amplification mix at working solution was added to each cup of emulsion oil. The cups were inverted 2-3 times to mix, placed on the TissueLyser (Qiagen/Retsch). The TissueLyser (Qiagen/Retsch) was shaken at 28 $\mathrm{Hz}$ for $5 \mathrm{~min}$ and the emulsion cups were removed from the TissueLyser (Qiagen/Retsch).

\section{DNA Library Capture}

The $1 \mathrm{X}$ capture bead wash buffer was prepared by mixing $1 \mathrm{ml}$ of $10 \mathrm{X}$ capture bead wash buffer with $9 \mathrm{ml}$ of MBGW. The tubes of DNA capture beads were vortex. The beads were pelleted, by spinning at $180 \mathrm{rpm}$ for $10 \mathrm{~s}$. The supernatant was carefully discarded without disturbing the bead pellet. The tubes of beads was washed twice using $1 \mathrm{ml}$ of $1 \mathrm{X}$ capture bead wash buffer TW. The beads were suspended by vortex, spun and the supernatant was removed. Rapid library method was used to denature the DNA, with the heated lid on at $95^{\circ} \mathrm{C}$ for $2 \mathrm{~min}$, then $4^{\circ} \mathrm{C}$ on hold. Each tube of washed DNA capture beads was added with the correct volume of the DNA library that will provide optimal 
amplification (e.g. per titration) to the bead pellet by using the following equation:

$$
\mu \mathrm{l} \text { of library per tube }=\frac{\begin{array}{c}
\text { Desired molecules per } \\
\text { bead } \times 35 \times 10^{6} \text { beads per tube }
\end{array}}{\begin{array}{c}
\text { Library concentration } \\
(\text { molecules } / \mu \mathrm{l})
\end{array}}
$$

The tubes were vortex for $5 \mathrm{~s}$ prior to adding the library DNA mixtures for individual emulsion reactions. The captured library mixtures was transferred from their DNA capture beads tubes to individual $15 \mathrm{ml}$ tubes, followed by addition of 3.75 $\mathrm{ml}$ Live Amplification mix. One $\mathrm{ml}$ of the mixture was pipetted into the original DNA capture beads tubes which contained the captured library. Then, the solution was vortex and transferred back into the $15 \mathrm{ml}$ tubes. This step was repeated twice.

\section{Emulsification}

The captured library in each $15 \mathrm{ml}$ tube was poured into an emulsion cup. The cups were inverted three times for mixing before shaken in the TissueLyser at $12 \mathrm{~Hz}$ for $5 \mathrm{~min}$. Hundred $\mu \mathrm{l}$ of emPCR amplification mixtures were dispensed into each 96-well thermocycler plates. The wells were capped and properly sealed. The plates containing the emulsified amplification reactions were placed in a thermocycler, and the amplification programme was run for $6 \mathrm{hr}$.

\section{Emulsion Collection, Bead Washes and Recovery}

The enhancing fluid XT and the annealing buffer XT were retrieved at RT. A $50 \mathrm{ml}$ conical tube was attached to each of the two lids of the emPCR breaking kit LV/MV. The blue connector was inserted into the top opening of the eightpronged transpipette. The other end of the tubing was connected to a vacuum source (with liquid trap to capture the isopropanol waste).

The emulsions from each emulsion cup was aspirated, 8 wells at a time and was collected in two $50 \mathrm{ml}$ collection tubes by using a slow circular motion of the transpipette tips at the bottom of the wells. After aspirating all the emulsions, the transpipette was turned upside-down to help drain as much material as possible into the collection tubes. The plates were rinsed twice with $100 \mu \mathrm{l}$ of isopropanol per well. Each tube was vortex and the $50 \mathrm{ml}$ collection tubes were mixed in pairs by transferring their contents back and forth. Isopropanol was added to a final volume of $40 \mathrm{ml}$ in each collection tube and vortex. The beads were centrifuged at $2000 \mathrm{rpm}$ for $5 \mathrm{~min}$ and the supernatant was carefully removed. A volume of $35 \mathrm{ml}$ of enhancing fluid XT was added and vortex. The samples were centrifuged, supernatant discarded before isopropanol was added. This step was repeated twice. Thirty-five $\mathrm{ml}$ of enhancing fluid XT was added and vortex. The samples were centrifuged and the supernatant was discarded, leaving approximately $2 \mathrm{ml}$ of enhancing fluid XT. The DNA bead suspension was transferred into two 1.7 $\mathrm{ml}$ tubes for each emulsion cup processed. Samples were spun-rotated-spun before the supernatant was discarded. Each of the $50 \mathrm{ml}$ collection tubes were rinsed with $600 \mu \mathrm{l}$ of enhancing fluid XT, vortex and added into the $1.7 \mathrm{ml}$ tubes. The tubes were spunrotated-spun and the supernatant was discarded. Each bead pellet was rinsed thoroughly twice using $1 \mathrm{ml}$ of enhancing fluid XT then spun-rotated-spun before the supernatant was discarded. A volume of $1 \mathrm{ml}$ of enhancing fluid XT was added to each bead pellet and vortex.

\section{Library Bead}

The dry-block was heated at $65^{\circ} \mathrm{C}$. The melt solution was prepared by mixing $125 \mu$ l of $10 \mathrm{~N}$ $\mathrm{NaOH}$ in $9.875 \mathrm{ml}$ of MBGW. The tubes containing the beads were spun-rotated-spun, the supernatant was discarded before adding one $\mathrm{ml}$ of melt solution per tube of beads and vortex. The tubes were incubated for $2 \mathrm{~min}$ at RT then spun-rotatedspun, before the supernatant was discarded. Subsequently, one $\mathrm{ml}$ of annealing buffer XT was added into each tube of beads, vortex then spunrotated-spun before the supernatant was discarded. Forty-five $\mu \mathrm{l}$ of annealing buffer XT and $25 \mu \mathrm{l}$ enrichment primer was added into each tube. The tubes were placed in a heat block set at $65^{\circ} \mathrm{C}$ for 5 min, and cooled on ice for $2 \mathrm{~min}$. A volume of 800 $\mu \mathrm{l}$ of enhancing fluid XT was added per tube and vortex. The tubes were subsequently spun-rotatedspun before the supernatant was discarded. A volume of $1 \mathrm{ml}$ of enhancing fluid XT was added per tube and vortex. The tubes were spun-rotatedspun then the supernatant was discarded. A volume of $800 \mu \mathrm{l}$ of enhancing fluid XT was added per tube and vortex.

\section{Enrichment of DNA-carrying Beads}

The tube of enrichment beads was vortex for 1 min to suspend its contents. The enrichment beads were pelleted using MPC. The supernatant was discarded and $1 \mathrm{ml}$ of enhancing fluid XT was added and vortex. The enrichment beads were pelleted using the MPC, before the supernatant was discarded. A volume of $160 \mu \mathrm{l}$ of enhancing fluid XT was added into each emulsion cup and vortex. Eighty $\mu \mathrm{l}$ of washed enrichment beads was added into each tube of amplified DNA beads and vortex. The tubes were rotated at RT for $5 \mathrm{~min}$ before placing in the MPC for 3-5 min to pellet the enrichment beads. The MPC was inverted several 
times. The supernatant was discarded from each tube using a $1000 \mu \mathrm{l}$ pipette.

The tubes of enriched beads were removed from the MPC and each bead pellet was suspended in $700 \mu \mathrm{l}$ of melt solution. The enrichment tubes were vortex for $5 \mathrm{~s}$ and placed in the MPC. The supernatant containing enriched DNA beads were transferred from each sample into a corresponding $1.7 \mathrm{ml}$ collection tube. Each $1.7 \mathrm{ml}$ collection tube was spun-rotated-spun, before the supernatant was discarded. The above rinsing method was repeated. A volume of $1 \mathrm{ml}$ of annealing buffer XT was added into each collection tube, vortex for $5 \mathrm{~s}$, then spun-rotated-spun before the supernatant was discarded. Each bead pellet was suspended in $200 \mu \mathrm{l}$ of annealing buffer XT.

\section{Sequencing Primer Annealing}

Fifty $\mu \mathrm{l}$ of sequencing primer was added to each collection tube and vortex, before placing in a heat block at $65^{\circ} \mathrm{C}$ for $5 \mathrm{~min}$ and on ice for 2 min. Eight hundred $\mu$ l of annealing buffer XT was added per collection tube, vortex for $5 \mathrm{~s}$, then spun-rotated-spun before the supernatant was discarded. One $\mathrm{ml}$ of annealing buffer XT was added to each bead pellet and vortex. Three $\mu \mathrm{l}$ of the beads was count with a particle counter to determine the percentage of bead enrichment by using the following equation:

$$
\% \text { Bead enrichment }=\frac{\text { Number of enriched beads }}{35 \times 10^{6} \text { beads } / \text { cup }} \times 100
$$

Percentage of enrichment values should be between $5 \%$ to $20 \%$ which indicated libraries that yield good sequencing results. The beads were stored at $2^{\circ} \mathrm{C}$ to $8^{\circ} \mathrm{C}$ before sequencing. The amplicons were sequenced at the Malaysia Genome Institute using the 454 GS-FLX Titanium protocol (454 Life Sciences / Roche Diagnostics, USA), which yields reads length of $400 \mathrm{bp}$.

\section{Post-run Analysis Using QIIME Pipelines (Caporaso et al., 2010)}

The DNA sequence reads were filtered for quality. Operational Taxonomic Units (OTU) were picked based on sequence similarity within the reads, a representative sequence from each OTU was picked. The OUT were assigned to a taxonomic identity using reference databases (SILVA release 108) (Quast et al., 2013). The OTU sequences were aligned and phylogenetic trees were constructed. The diversity metrics for each sample were calculated and the types of communities were compared using the taxonomic and phylogenetic assignments. The UPGMA, PCoA, 3D Bi-Plot and taxonomic composition were generated to visually depict the differences between the samples, and dynamically work with these graphs to generate publication quality figures.

\section{RESULTS AND DISCUSSION}

The average moisture content, $\mathrm{pH}$ and rainfall in April 2012 for the four peat ecosystems are as in Table 1. The $\mathrm{pH}$ was most acidic, 3.3 for the 11 years old oil palm plantation at Naman, followed by 3.4 for 7 years old oil palm plantation at Durafarm, 3.6 for Maludam National Park and was least acidic, 3.7 for the partially drained logged-over peatland at Cermat Ceria. Although total rainfall in April 2012 was 164 $\mathrm{mm}$ for peatland at Maludam which was higher than Cermat Ceria, $101.5 \mathrm{~mm}$ but the average moisture content of the peatland in Maludam was $42.3 \%$ very much lower than $204.2 \%$ for the partially drained logged-over peatland at Cermat Ceria because of the dry season, absence of drainage system which led to irreversible drying in the primary peatland. As for the oil palm cultivated area at Durafarm and Naman, the rainfall was high, $257.5 \mathrm{~mm}$ and 241.5 $\mathrm{mm}$, respectively, more than double recorded at Cermat Ceria, $101.5 \mathrm{~mm}$ but the moisture content was well maintained at $181.1 \%$ and $139.38 \%$ for two oil palm plantations as compared to Cermat Ceria, $204.2 \%$ (Table 1). Sufficient water availability and management is important for palm growth and high yield. Insufficient or excessive water in the palm rooting zone will adversely affect nutrient uptake and FFB production (Lim et al., 2012). A good water management system for oil palm on peat can effectively maintain water level of $50-75 \mathrm{~cm}$ from the peat surface (Lim et al., 2012), which is crucial for avoiding irreversible drying, reduce $\mathrm{CO}_{2}$ emission,

TABLE 1. MOISTURE CONTENT AND pH FOR DIFFERENT PEAT ECOSYSTEMS

\begin{tabular}{lccc}
\hline Sites & Moisture content $\mathbf{( \% )}$ & $\mathbf{p H}$ & Rainfall ( $\mathbf{m m}^{3} \mathbf{)}$ \\
\hline Maludam $^{1}$ & $42.3 \pm 8.2$ & $3.6 \pm 0.1$ & 164.0 \\
Cermat Ceria $^{2}$ & $204.2 \pm 48.3$ & $3.7 \pm 0.1$ & 101.5 \\
Durafarm $^{3}$ & $181.1 \pm 35.5$ & $3.4 \pm 0.1$ & 257.5 \\
Naman $^{4}$ & $139.4 \pm 40.6$ & $3.3 \pm 0.1$ & 241.0 \\
\hline
\end{tabular}

Note: ${ }^{1}$ Maludam - peatland, ${ }^{2}$ Cermat Ceria - logged-over peatland,

${ }^{3}$ Durafarm - 7 years old oil palm, ${ }^{4}$.Naman - 11 years old oil palm. 
minimise peat oxidation and subsidence (Hooijer et al., 2012).

\section{Analysis of 454 Pyrosequencing Data}

A total of 176228 16SrRNA raw sequencing reads was obtained for 10 samples subjected to 454 pyrosequencing for Maludam National Park, 369693 raw sequencing reads for Cermat Ceria, 288005 raw sequencing reads for Durafarm and 369693 raw sequencing reads for Naman (Table 2). While the total number of sequences passing quality filters was 65627 for Maludam National Park, 152266 for Cermat Ceria, 252971 for Durafarm and 175364 for Naman. The average high quality sequence read length was comparable, 428 bp for Maludam National Park, 429 bp for Cermat Ceria, 426 bp for Durafarm and $430 \mathrm{bp}$ for Naman. Comparable average sequences passing quality filters (HQ) was obtained for all peat ecosystems, 394 for Maludam National Park, 395 for Cermat Ceria, 392 for Durafarm and 396 for Naman. All chimeras and singletons were removed before further analysis. For the 10 samples, the total number and percentage sequences passing quality filters (HQ) or remained after quality control and chimera detection was 65627 reads $(37 \%)$ for Maludam National Park, 152266 (41\%) for Cermat Ceria, 252971 (88\%) for Durafarm and 175364 (47\%) for Naman (Table 2).

\section{Operational Taxonomic Unit and Observed Species versus Sequence per Sample ID}

The operational taxonomic unit (OTU) was 986 for Maludam, 1853 for Cermat Ceria, 1677 for Durafarm and 865 for Naman (Table 3) which tallied with alpha diversity or the simplest measure of biodiversity which is species richness, which measure the number of species found in a given area, niche or habitat. Based on the OTU and $\alpha$-diversity for the logged-over forest at Cermat Ceria showed the highest eaukaryotic biodiversity because it consistently showed the highest number of exclusive species for each of the ten samples (Figure 2b) followed by Durafarm (Figure 2c), Naman (Figure 2d) and Maludam (Figure 2a). The

TABLE 2. SAMPLE STATISTICS FOR PROCESSING DATA

\begin{tabular}{|c|c|c|c|c|}
\hline Sample parameters & Maludam Nat. Park & Cermat Ceria & Durafarm & Naman \\
\hline Number raw input sequences & 176228 & 369693 & 288005 & 369693 \\
\hline Length outside bounds of 200 and 1000 bp & 4533 & 6464 & 5079 & 6464 \\
\hline Num ambiguous bases exceeds limit of 6 & 67 & 32 & 46 & 32 \\
\hline Missing qual score & 0 & 0 & 0 & 0 \\
\hline Mean qual score below minimum of 25 & 56 & 166 & 112 & 166 \\
\hline Max homopolymer run exceeds limit of 6 & 7416 & 11231 & 867 & 11231 \\
\hline Num mismatches in primer exceeds limit of 0 : & 98348 & 24079 & 28445 & 24079 \\
\hline Uncorrected barcodes & 181 & 175455 & 485 & 152357 \\
\hline \multicolumn{5}{|c|}{ Sequence length details for all sequences passing quality filters: } \\
\hline Raw length: minimum & 201 & 200 & 200 & 200 \\
\hline maximum & 580 & 570 & 623 & 554 \\
\hline average & 428 & 429 & 426 & 430 \\
\hline HQ length: minimum & 167 & 166 & 166 & 166 \\
\hline maximum & 546 & 536 & 589 & 520 \\
\hline average & 394 & 395 & 392 & 396 \\
\hline Total number sequences passing quality filters (HQ) & 65627 & 152266 & 252971 & 175364 \\
\hline
\end{tabular}

TABLE 3. TOTAL OPERATIONAL TAXANOMIC UNIT (OTU) FOR DIFFERENT SITES

\begin{tabular}{lc}
\hline Sites & Total OTU \\
\hline Maludam National Park $^{1}$ & 986 \\
Cermat Ceria $^{2}$ & 1853 \\
Durafarm $^{3}$ & 1677 \\
Naman $^{4}$ & 865 \\
\hline
\end{tabular}

Note: ${ }^{1}$ Maludam - peatland, ${ }^{2}$ Cermat Ceria - loggedover peatland, ${ }^{3}$ Durafarm -7 years old oil palm, ${ }^{4}$ Naman - 11 years old oil palm. $\alpha$-diversity of eukaryotic community for Maludam indicated lowest average species per sample ID of 65 species (Figure 2a) as compared to 450 species per sample ID for Cermat Ceria (Figure 2b), 400 for Durafarm (Figure 2c) and 200 species per sample ID for Naman (Figure 2d). While, the sequence per sample ID ranged 400 - 500 for Maludam (Figure 2a), 11000 - 16000 for Cermat Ceria (Figure 2a), 17000 24000 for Durafarm (Figure 2c) and 16000 - 18000 for Naman (Figure 2d). 

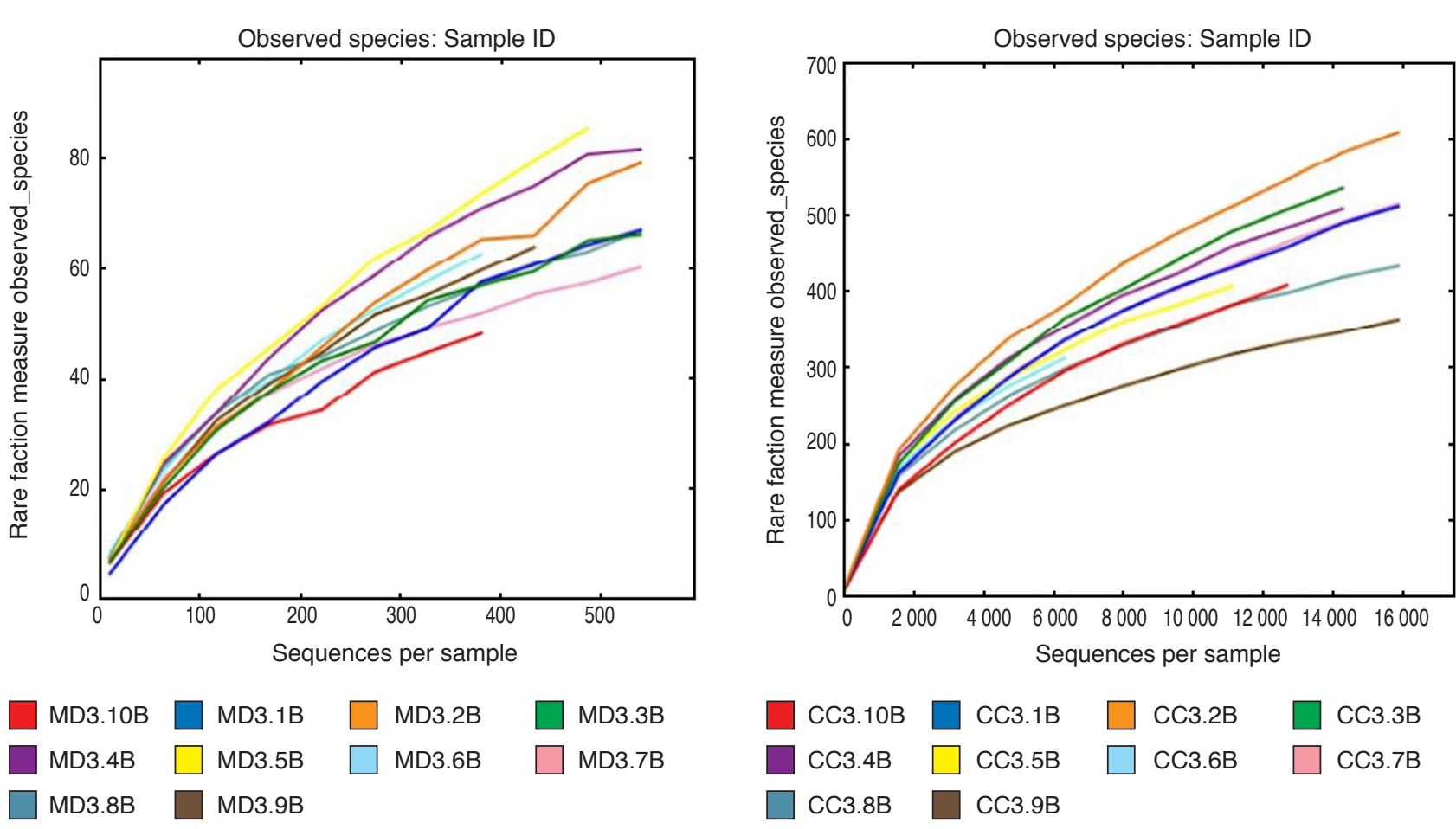

Figure 2a. Observed species versus sequence per sample ID for Maludam National Park (peatland) at Sri Aman, Sarawak, Malaysia.

Figure 2b. Observed species versus sequence per sample ID for Cermat Ceria (logged-over peatland) at Sri Aman, Sarawak, Malaysia.

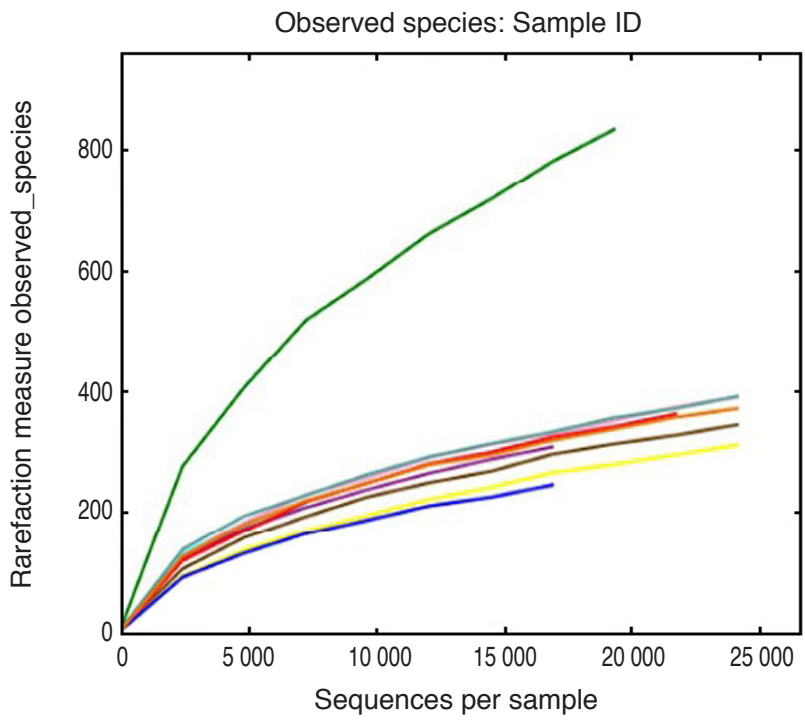

$\begin{array}{llllll}\square \text { DF3.10B } & \square \text { DF3.1B } & \square & \text { DF3.2B } & \square \text { DF3.3B } \\ \square \text { DF3.4B } & \square \text { DF3.5B } & \square & \text { DF3.6B } & \square \text { DF3.7B } \\ \square \text { DF3.8B } & \square \text { DF3.9B }\end{array}$

Figure 2c. Observed species versus sequence per sample ID for mature oil palm (7 years old) at Durafarm Sri Aman, Sarawak, Malaysia.

The lowest OTU and $\alpha$-diversity at Muladam was probably attributed by the lowest moisture content (Table 1) and irreversible drying of the peatland during dry spelt in April 2012 in the absence of water management system as documented by (Lim et al., 2012).

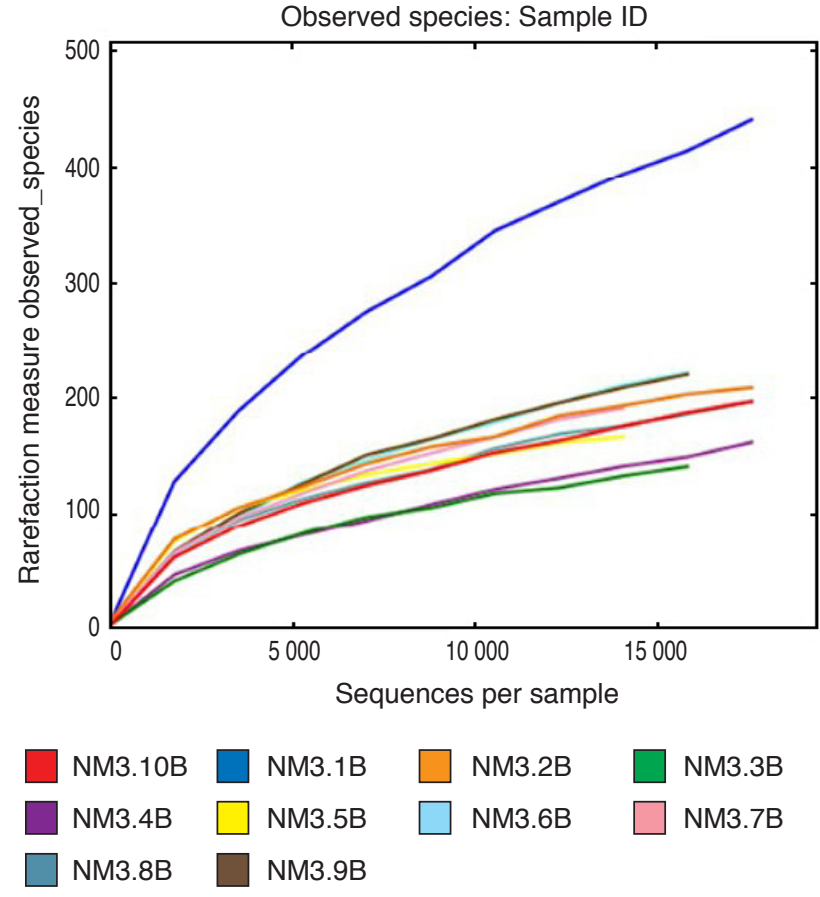

Figure 2d. Observed species versus sequence per sample ID for mature oil palm (11 years old) at Naman in Sibu, Sarawak, Malaysia.

\section{Generate 3D Bi-plot and Taxonomic Composition}

Generate 3D Bi-Plot and taxonomic composition of eukaryotic community indicated the population at Maludam National Park comprised of fungi, Aleolata and Ciliphora (Figure 3a) and other 


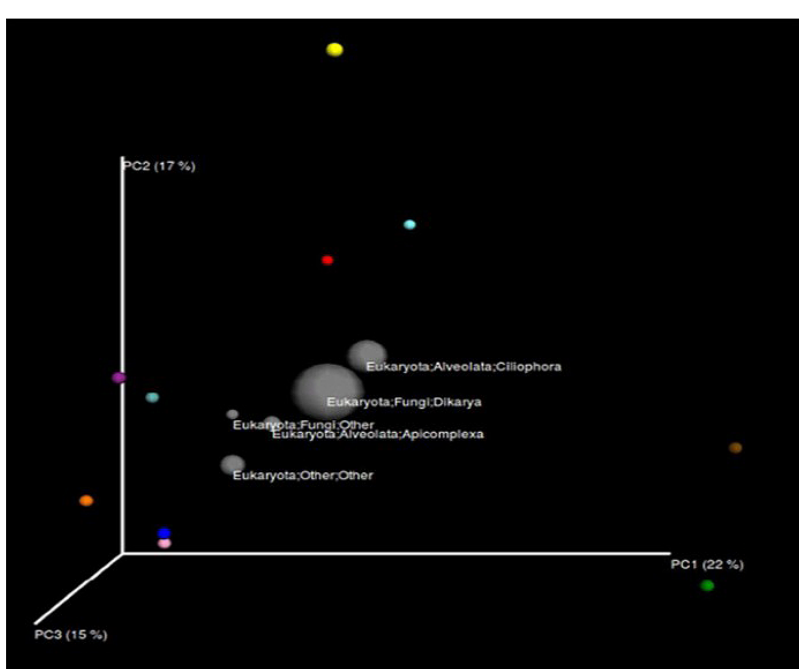

\begin{tabular}{|c|c|c|c|}
\hline MD3.10B & MD3.1B & MD3.2B & MD3.3B \\
\hline MD3.4B & MD3.5B & MD3.6B & MD3.7B \\
\hline $3.8 B$ & $3.9 \mathrm{~B}$ & & \\
\hline
\end{tabular}

Figure 3a. Generate 3D Bi-Plot for samples taken at Maludam National Park (peatland) at Sri Aman, Sarawak, Malaysia.
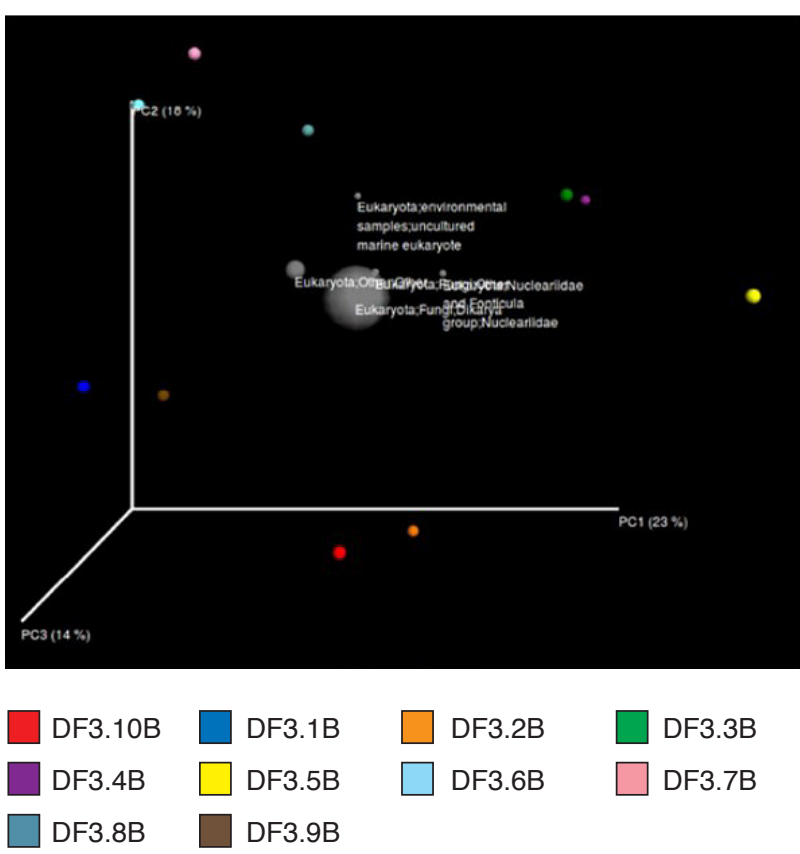

Figure 3c. Generate 3D Bi-Plot for peat samples taken under (7years old oil palm) at Durafarm, Sri Aman, Sarawak, Malaysia.

unclassified Eukaryota. As for in secondary loggedover peatland, Cermat Ceria (Figure 3b) and oil palm plantations at Durafarm (Figure 3c), Naman (Figure $3 d$ ) the eukaryotes population comprised mainly of fungi and other unclassified Eukaryota, since the high moisture content, acidity and low water table with drainage system promote better growth of fungi compared to low moisture at peatland during dry period.

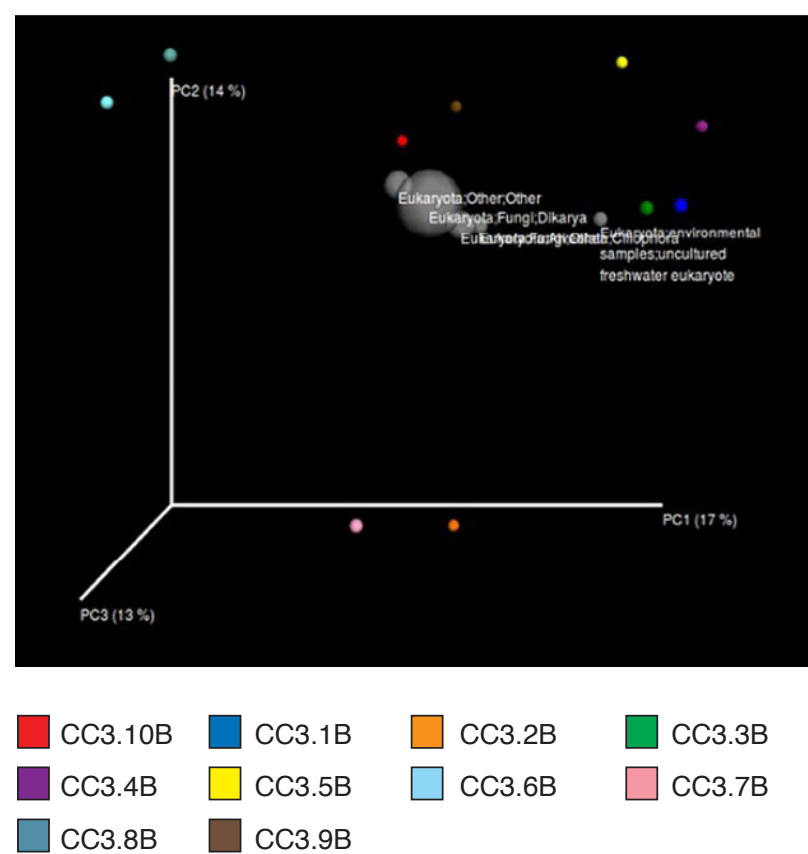

Figure 3b. Generate 3D Bi-Plot for samples taken at Cermat Ceria (logged-over peatland) at Sri Aman, Sarawak, Malaysia.

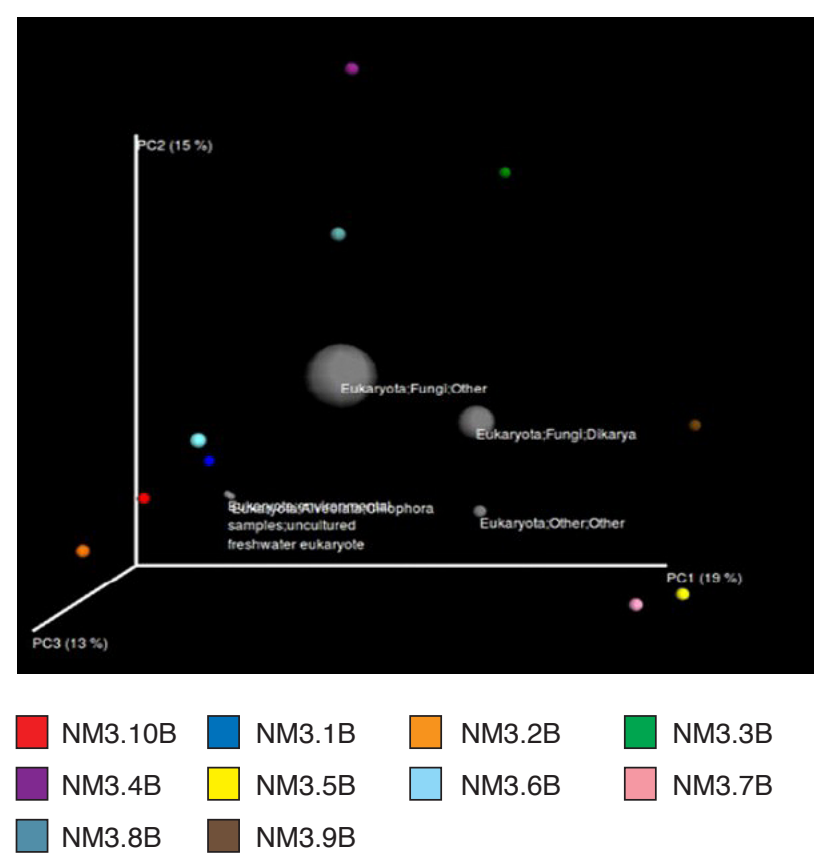

Figure 3d. Generate 3D Bi-Plot for peat samples taken under (11 years old oil palm) at Naman, Sibu, Sarawak, Malaysia.

\section{Taxanomic Profile of Eukaryotic OTU}

Based on the taxanomic profile of OTU, the two equally predominant phylotypes found at Maludam National Park were Alveolata (where Ciliphora more dominant than the Apicomplexa) followed by fungi (Dikarya comprising of the more dominant Ascomycetes, Basidiomycetes, other fungi and fungi incerta sedis) (Figure 4a), since the low acidity and 
moisture content during dry period and anaroxic peat surface in the monsoon in peatland were not conducive for the proliferation of fungi, although there was plenty of litters and organic matter. In the secondary logged-over mixed peat forest ecosystem the most dominant taxa observed were fungi (Ascomycetes being most dominant followed by other fungi, Basidiomycetes, Fungi inserta sedis and Chytridiomycota), Ciliophora and other Eukaryota (Figure $4 b$ ). In the mature oil palm at Durafarm, the most dominant taxa was fungi the Ascomycetes followed by Dikarya and other unclassified Eukaryota (Figure 4c). In Naman the dominant taxa was fungi (Figure $4 d$ ). For fungi, the phylum Ascomycota accounted for more than two thirds, followed by Basidiomycota and Glomeromycota (Urich et al., 2008, Siti Ramlah et al., 2016).

\section{OTU-based Major Eukaryotes}

Based on the statistical analysis of OTU for the different mixed peat ecosystems, fungi was the most dominant eukaryotes comprising of 45.12\% for Maludam, 55.93\% for Cermat Ceria, $73.23 \%$ for Durafarm and $88.67 \%$ for Naman (Table 4). With partial drainage and logging, the fungi population significantly increased at $\alpha$ value of 0.05 , from $45.12 \%$ at Maludam to $55.93 \%$ at Cermat Ceria, because of the higher moisture content (Table 1) and more aerobic peat surface for Cermat Ceria. With the cultivation of oil palm and further management of water level via block drainage system and increased moisture content as well as peat acidity (Table 1) the fungi population increased further to $73.23 \%$ at Durafarm and $88.67 \%$ at Naman, significantly different at $\alpha$ value of 0.05 , as compared to the peatlands (Table 4). The second most dominant phylum, predatory Alveolata was $28.84 \%$, significantly higher at $\alpha$ value of 0.05 in the peatland at Maludam as compared to $10.36 \%$ in logged-over peatland, Cermat Ceria (Table 4). With the development of logged-over peatland to oil palm plantation, the percentage of Alveolata significantly reduced at $\alpha$ value of 0.05 , from $10.36 \%$ in Cermat Ceria to $2.46 \%$ at Durafarm and $1.80 \%$ at Naman, probably due to low water table which reduced the aquatic flora and fauna for the survival of the predatory and parasitic Alveolata (Table 4). Also, the high acidity of the oil palm cultivated areas which increased the fungal diversity hence reduced the Alveolata diversity. The prevalence of fungi and Alveolata amongst other eukaryotes in this study, tallied with earlier findings of (Guillou et al., 2013) on eukaryotes, which indicated $54 \%$ of total sequences belong to Opisthonkonta or fungi, followed by Alveolata, 15\% and Archaeplastida, 12\%.

Occurrence of other unidentified eukaryotes for all ecosystems was not significantly different at $\alpha$ value of 0.05 , in Maludam National Park 6.39\%, Cermat Ceria $10.96 \%$, Durafarm $13.84 \%$ and Naman $15.57 \%$, although it increased with cultivation and age of oil palm (Table 4). Some unknown

TABLE 4. PERCENTAGE OF MAJOR, MINOR AND RARE EUKARYOTES FOR THE DIFFERENT PEAT ECOSYSTEMS

\begin{tabular}{|c|c|c|c|c|c|c|c|c|}
\hline \multirow[b]{2}{*}{ Sites } & \multicolumn{8}{|c|}{ Percentage of major eukaryota } \\
\hline & \multicolumn{3}{|c|}{ Fungi } & \multicolumn{2}{|c|}{ Alveolata } & \multicolumn{2}{|c|}{ Eukaryota spp. } & Env. samples \\
\hline Maludam $^{1}$ & \multicolumn{3}{|c|}{$45.12 \pm 2.9 \mathrm{a}$} & \multicolumn{2}{|c|}{$28.84 \pm 3.9 c$} & \multicolumn{2}{|c|}{$10.96 \pm 5.9 a$} & $5.54 \pm 1.3 \mathrm{ab}$ \\
\hline Cermat Ceria $^{2}$ & \multicolumn{3}{|c|}{$55.93 \pm 3.2 b$} & \multicolumn{2}{|c|}{$10.36 \pm 1.7 b$} & \multicolumn{2}{|c|}{$13.84 \pm 3.0 \mathrm{a}$} & $8.64 \pm 2.1 c$ \\
\hline Durafarm $^{3}$ & \multicolumn{3}{|c|}{$73.23 \pm 4.5 c$} & \multicolumn{2}{|c|}{$2.46 \pm 0.6 \mathrm{a}$} & \multicolumn{2}{|c|}{$15.57 \pm 3.5 a$} & $3.68 \pm 1.3 \mathrm{a}$ \\
\hline \multirow[t]{2}{*}{ Naman $^{4}$} & \multicolumn{3}{|c|}{$87.64 \pm 2.9 \mathrm{~d}$} & \multicolumn{2}{|c|}{$1.80 \pm 0.6 \mathrm{a}$} & \multicolumn{2}{|c|}{$6.39 \pm 1.8 \mathrm{a}$} & $1.55 \pm 0.4 \mathrm{a}$ \\
\hline & \multicolumn{8}{|c|}{ Percentage of minor eukaryota } \\
\hline Sites & $\begin{array}{c}\text { Unassignes } \\
\text { other spp. }\end{array}$ & \multicolumn{2}{|c|}{$\begin{array}{l}\text { Nucleariidae spp } \\
\mathcal{E} \text { Fonticula spp. }\end{array}$} & \multicolumn{2}{|c|}{$\begin{array}{l}\text { Rhizaria } \\
\text { spp. }\end{array}$} & $\begin{array}{c}\text { Stramenopiles } \\
\text { spp. }\end{array}$ & $\begin{array}{c}\text { Ameoboza } \\
\text { spp. }\end{array}$ & $\begin{array}{c}\text { Choaflagelida } \\
\text { spp. }\end{array}$ \\
\hline Maludam $^{1}$ & $2.47 \pm 1.1 \mathrm{~b}$ & \multicolumn{2}{|l|}{$2.75 \pm 0.9 \mathrm{~b}$} & \multicolumn{2}{|c|}{$1.58 \pm 0.2 b$} & $1.42 \pm 0.7 \mathrm{ab}$ & $0.94 \pm 0.2 b$ & $0.18 \pm 0.1 \mathrm{ab}$ \\
\hline Cermat Ceria $^{2}$ & $2.35 \pm 0.6 \mathrm{ab}$ & \multicolumn{2}{|c|}{$1.72 \pm 0.8 \mathrm{ab}$} & \multicolumn{2}{|c|}{$1.70 \pm 0.3 b$} & $2.17 \pm 0.6 b$ & $1.59 \pm 0.3 c$ & $1.06 \pm 0.3 b$ \\
\hline Durafarm $^{3}$ & $0.62 \pm 0.19 \mathrm{ab}$ & \multicolumn{2}{|c|}{$1.51 \pm 0.7 \mathrm{ab}$} & \multicolumn{2}{|c|}{$0.66 \pm 0.1 \mathrm{a}$} & $0.42 \pm 0.3 a$ & $0.57 \pm 0.1 \mathrm{ab}$ & $0.01 \pm 0.1 \mathrm{a}$ \\
\hline Naman $^{4}$ & $0.41 \pm 0.2 \mathrm{a}$ & $0.47 \pm 0.1 \mathrm{a}$ & & 0.54 & $0.1 \mathrm{a}$ & $6 \pm 0.3 a$ & $0.06 \pm 0.0 \mathrm{a}$ & $0.65 \pm 0.5 \mathrm{ab}$ \\
\hline & & & & Perce & tage of rare euk & cyota & & \\
\hline Sites & $\begin{array}{l}\text { Metazoa } \\
\text { spp. }\end{array}$ & $\begin{array}{c}\text { Micronuclearia } \\
\text { spp. }\end{array}$ & Virid & intae & $\begin{array}{c}\text { Centroheliozoa } \\
\text { spp. }\end{array}$ & $\begin{array}{l}\text { Trimastix } \\
\text { spp. }\end{array}$ & $\begin{array}{l}\text { Soil amoeba } \\
\quad \& 16\end{array}$ & $\begin{array}{c}\text { Haptophyceae } \\
\text { spp. }\end{array}$ \\
\hline Maludam $^{1}$ & $0.15 \pm 0.1 b$ & $0.02 \pm 0.0 \mathrm{a}$ & 0.01 & & $0 \pm 0 \mathrm{a}$ & $0 \pm 0 \mathrm{a}$ & $0 \pm 0 \mathrm{a}$ & $0 \pm 0 \mathrm{a}$ \\
\hline Cermat Ceria $^{2}$ & $0.15 \pm 0.0 \mathrm{~b}$ & $0 \pm 0 \mathrm{a}$ & 0.04 & & $0.28 \pm 0.3 a$ & $0.14 \pm 0.1 b$ & $0.01 \pm 0.01 \mathrm{a}$ & $0 \pm 0 \mathrm{a}$ \\
\hline Durafarm $^{3}$ & $0.02 \pm 0.0 \mathrm{a}$ & $0 \pm 0 \mathrm{a}$ & 0.02 & & $1.16 \pm 1.2 \mathrm{a}$ & $0 \pm 0 \mathrm{a}$ & $0.01 \pm 0.01 \mathrm{a}$ & $0.04 \pm 0.04 a$ \\
\hline Naman $^{4}$ & $0 \pm 0 \mathrm{a}$ & $0 \pm 0 \mathrm{a}$ & 0.01 & & $0 \pm 0 \mathrm{a}$ & $0 \pm 0 \mathrm{a}$ & $0 \pm 0 \mathrm{a}$ & $0 \pm 0 \mathrm{a}$ \\
\hline
\end{tabular}

Note: ${ }^{1}$ Maludam - peatland, ${ }^{2}$ Cermat Ceria - logged-over peatland, ${ }^{3}$ Durafarm - 7 years old oil palm, ${ }^{4}$ Naman - 11 years old oil palm. Data with different letters are significantly different at $\alpha$ value of 0.05 . 


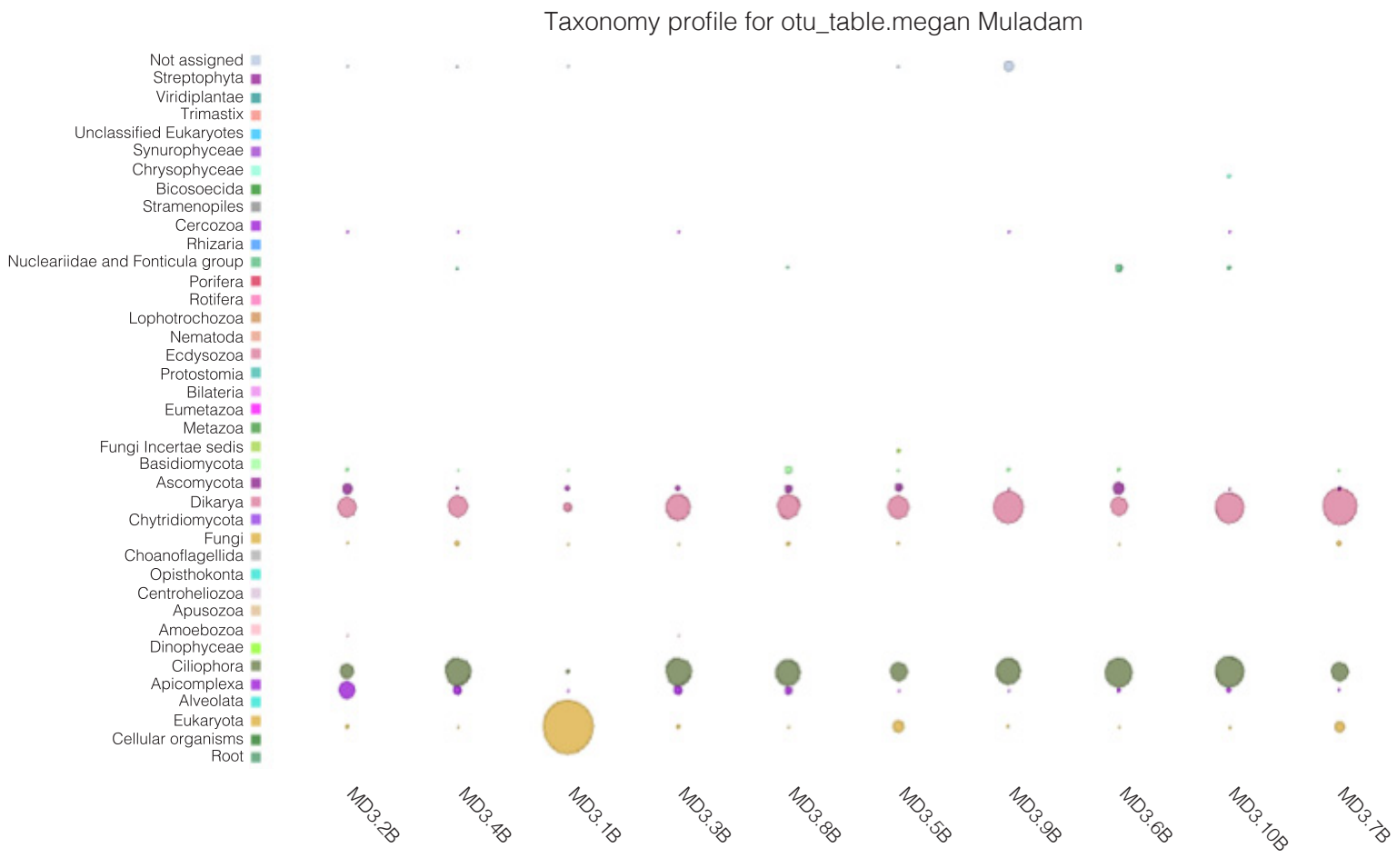

Figure 4a. Taxanomic profile of Eukaryotic operational taxonome unit (OTU) for Maludam National Park (peatland) at Seri Aman, Sarawak, Malaysia.

Taxonomy profile for otu_table.megan Cermat Ceria
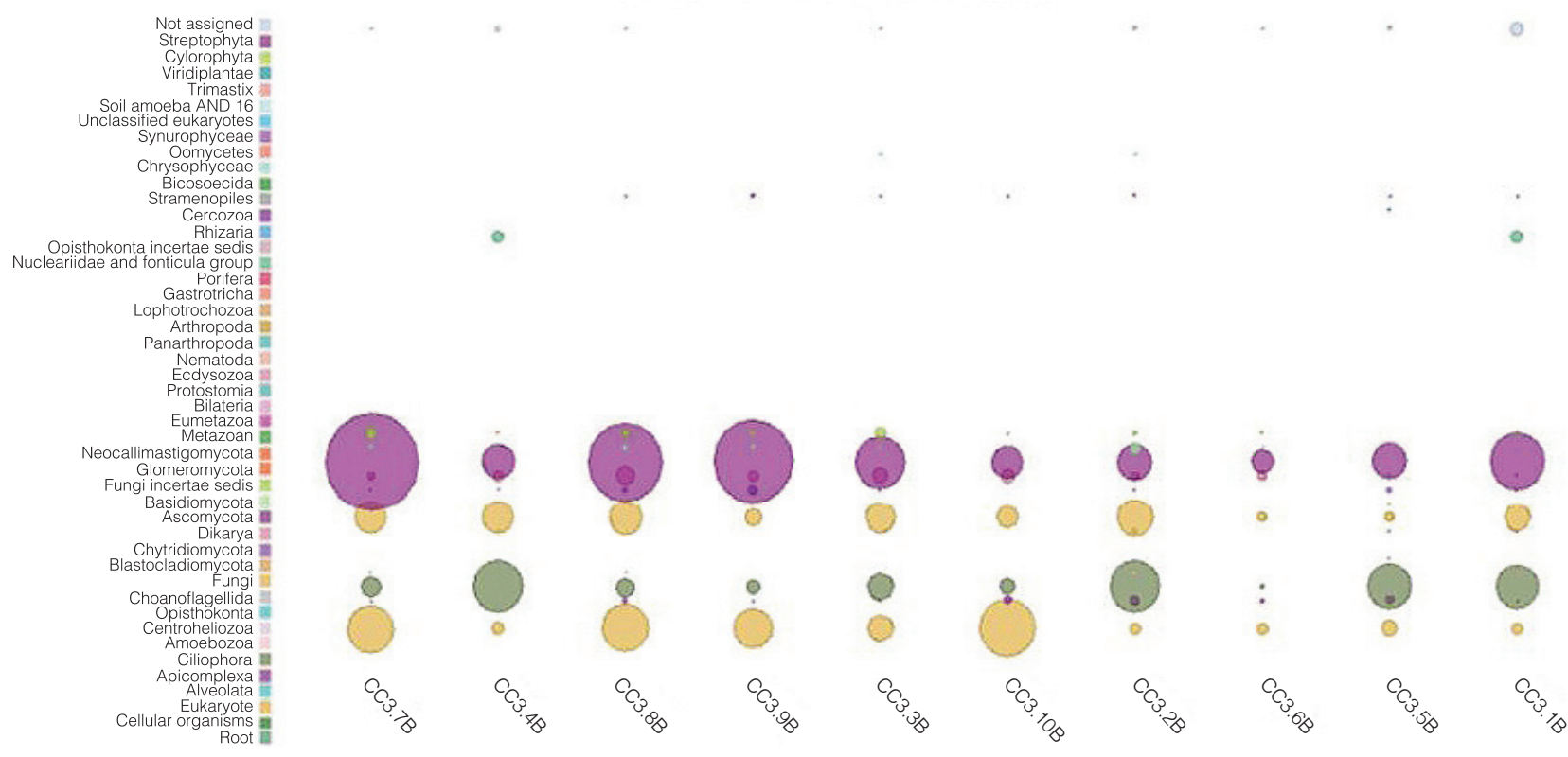

Figure 4b. Taxanomic profile of Eukaryotic operational taxonomic unit (OTU) for Cermat Ceria (logged-over forest) in Seri Aman, Sarawak, Malaysia.

environmental samples detected at $8.64 \%$ in Cermat Ceria significantly higher at $\alpha$ value of 0.05 , as compared to $5.54 \%$ in Maludam, $3.68 \%$ in Durafarm and $1.55 \%$ in Naman (Table 4). The interrogation of genetic markers in environmental studies is seriously hindered by the lack of taxonomically curated reference data sets for the targeted genes (Guillou et al., 2013).

\section{OTU-based Minor Eukaryotes}

Minor eukaryotic phyla which were higher in mixed forest peatland and logged-over peatland compared to oil palm plantations were Nuclearidae and Fonticula, Rhizaria, Stramenopiles and Amoebozoa (Table 4). Presence of Nuclearidae and Fonticula were significantly higher at $\alpha$ value 


\section{Taxonomy profile for otu_table.megan Durafarm}

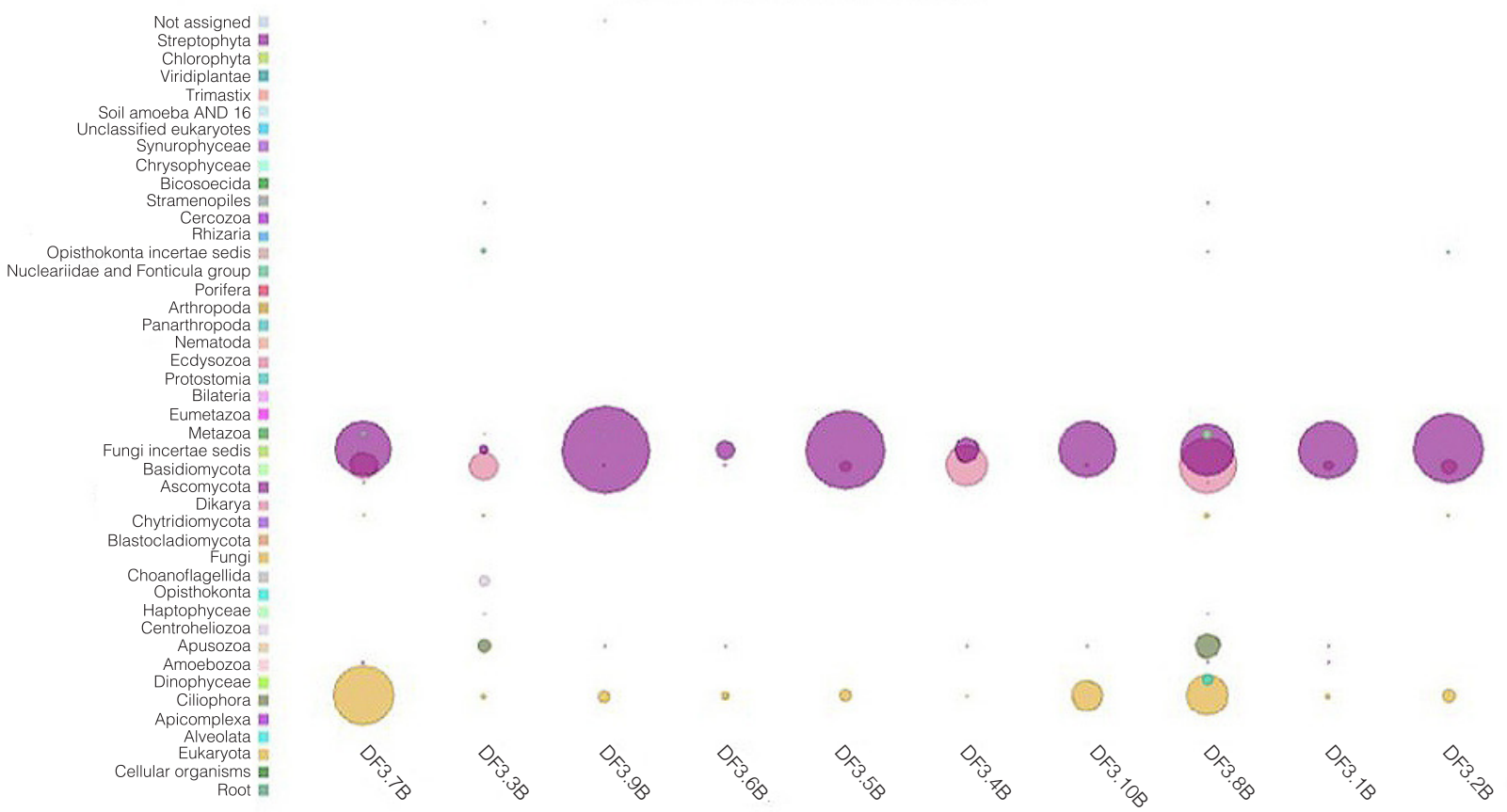

Figure 4c. Taxanomic profile of Eukaryotic operational taxonomic unit (OTU) for mature oil palm plantation (7 years old) Durafarm, at Seri Aman, Sarawak, Malaysia.

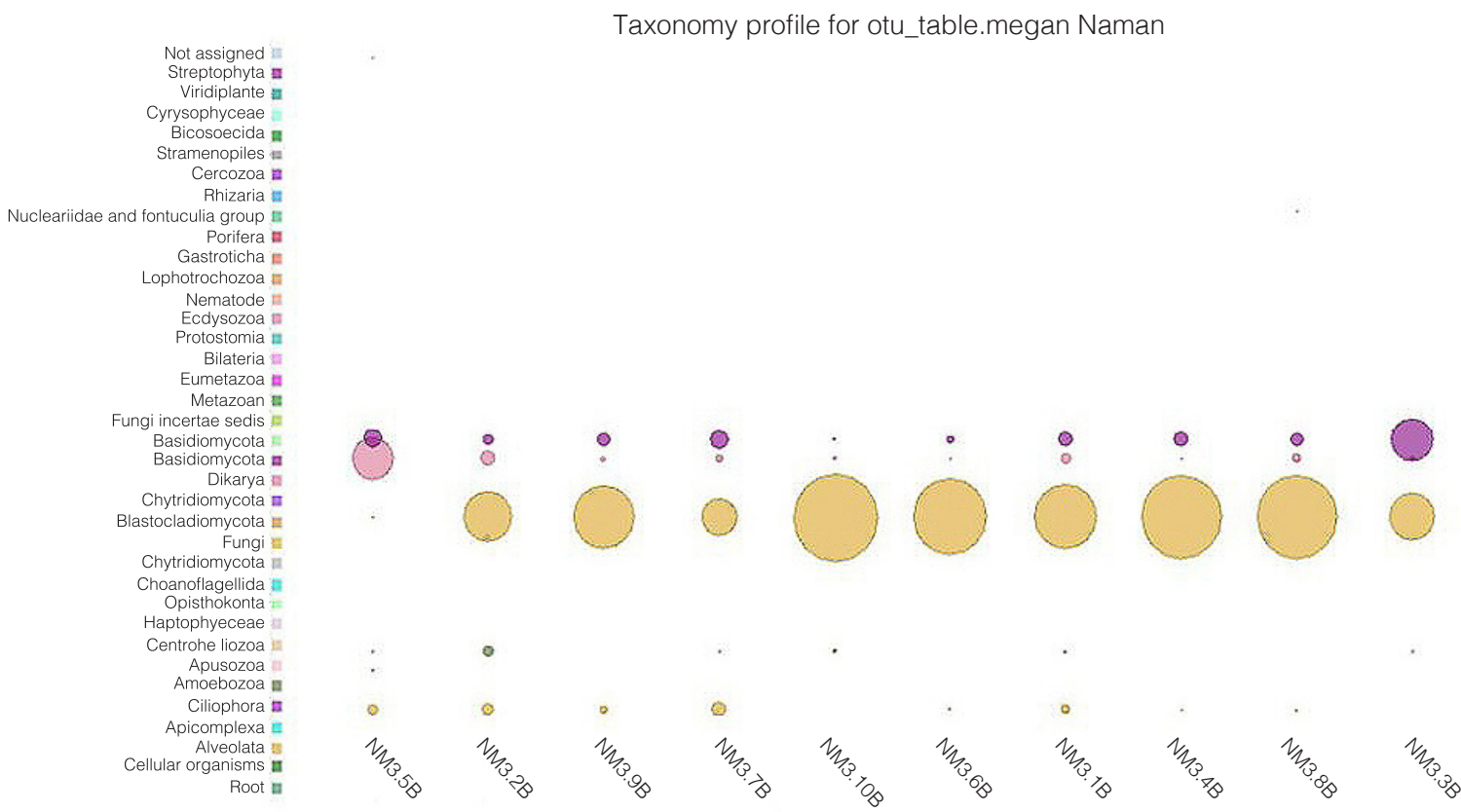

Figure 4d. Taxanomic profile of eukaryotic operational taxonomic unit (OTU) for mature oil palm plantation (11 years old) Naman at Seri Aman, Sarawak, Malaysia.

of 0.05 , at Maludam, $2.47 \%$ and logged-over peatland at Cermat Ceria, $2.36 \%$ as compared to matured oil palm plantations at Durafarm $0.62 \%$ and Naman $0.41 \%$ (Table 4). The percentage of Rhizaria in Maludam was $1.70 \%$ and Cermat Ceria $1.58 \%$ significantly higher at $\alpha$ value of 0.05 than at Durafarm $0.66 \%$ and Naman $0.54 \%$ (Table 4). So as, the population of Stramenopiles significantly higher at $\alpha$ value of 0.05 , in Maludam $2.17 \%$ and Cermat Ceria $1.42 \%$ as compared to Durafarm $0.46 \%$ and Naman $0.42 \%$ (Table 4) again due to high acidity of the oil palm cultivated areas which promote fungal growth and reduced the Alveolata diversity. Amoebozoa was still higher in both peatlands, but was significantly higher at $\alpha$ value of 0.05 , at Cermat Ceria $1.06 \%$ as compared to Maludam $0.65 \%$ and 
Durafarm 0.18\%. Amoebozoa in Naman was $0.01 \%$ significantly lower as compared to Maludam $0.65 \%$ and Durafarm $0.18 \%$ (Table 4). These protozoan heterotrophic ciliates and dinoflagellates, are major grazers on bacteria, flagellates, and diatoms which were more abundant in peatland than cultivated land (Seuthe et al., 2011). Single-cell eukaryotic microorganisms (i.e., protists) are ubiquitous in every ecosystem on earth and play critical ecological roles in food web dynamics and global carbon and nutrient cycles (Montagnes et al., 2012).

\section{OTU-based Rare Eukaryotes in Different Peat Ecosystems}

It was documented that Stramenopiles made up of $7.2 \%$ and Rhizaria $5.6 \%$ of eukaryotic population. Other groups occurred $<2.2 \%$ termed as rare or minor (Guillou et al., 2013). The rare eukaryotes which comprised of $1.2 \%$ or less were Choanoflaggellida, Viridiplantae, Metazoa, Centroheliozoa, Amoeba and 16 phylum, Micronuclearia, Trimastrix and Haptophycea (Table 4). Choanoflaggellida was detected in all peat ecosystems at less $0.06 \%$ and Viridiplantae $0.04 \%$ (Table 4). Metazoa was detected at Maludam, Cermat Ceria and Durafarm at less $0.15 \%$ and absent in Naman (Table 4). Centroheliozoa was found in Cermat Ceria and Durafarm at $1.2 \%$ and Amoeba $0.01 \%$ (Table 4). Micronuclearia in Maludam was detected at $0.02 \%, 0.14 \%$ Trimastric in Cermat Ceria and $0.04 \%$ Haptophycea in Durafarm (Table 4). The rare eukaryotic taxonomic groups include the Protista and Metazoa (Bailly et al., 2007).

\section{Phylogeny of Eukaryotic Phyla}

In general, fungi and Alveolata were the major groups of eukaryotes for all peat ecosystems as indicated by the size of the circles in Figures $5 a$ to $5 d$. The most prevalent phylum for fungi was the Ascomycota. As for Alveolata, the Ciliphora was dominant for all peat ecosystems as indicated by the size of the circles in Figures $5 a$ to $5 d$. The number of phyla observed was 28, highest at Durafarm (Figure $5 c$ ) followed by 27 at Cermat Ceria (Figure 5b), 23 for Maludam (Figure $5 a$ ) and 20 at Naman (Figure $5 d$ ).

The common fungal phyla for all peat ecosystems were Ascomycota, Basidiomycota, Fungi incertae sedis and Chytridiomycota. Glomeromycota and Neocallimastigomycota were present in logged-over peat at Cermat Ceria (Figure $5 b$ ) and absent in the other peat ecosystems (Figures $5 a, 5 c$ and $5 d$ ). Glomeromycota is the phylum for most arbuscular mycorrhizal fungi, which form symbioses with many herbaceous plants ( $\mathrm{Tu}$ et al., 2015) found in logged-over forest at Cermat Ceria, the low relative abundance of Glomeromycota resulted from perennial plant species composition (Tu et al., 2015) such as in Maludam and matured oil palm at Durafaram and Naman. Glomeromycota is an important soil microbial group that affects multiple ecosystem functions and processes, including nutrient cycling, plant productivity and competition, and plant diversity (Alguacil et al., 2016). Neocallimastigomycota found at Cermat Ceria are anaerobic fungi which can hydrolyse the most recalcitrant plant polymers (Ebersberger

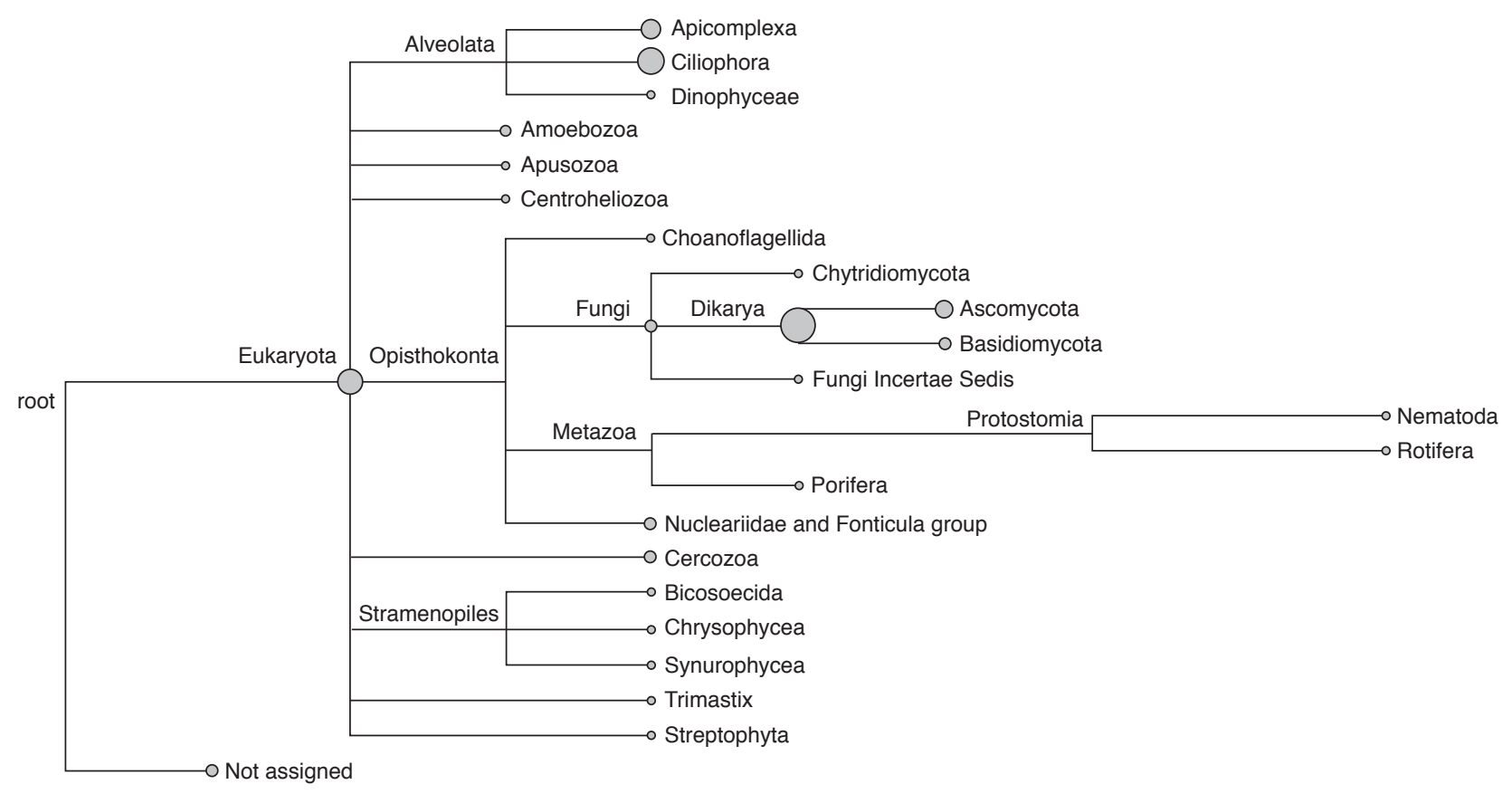

Figure 5a. Phylogeny of eukaryotic phyla at Maludam National Park (peatland forest) Sri Aman, Sarawak, Malaysia. 


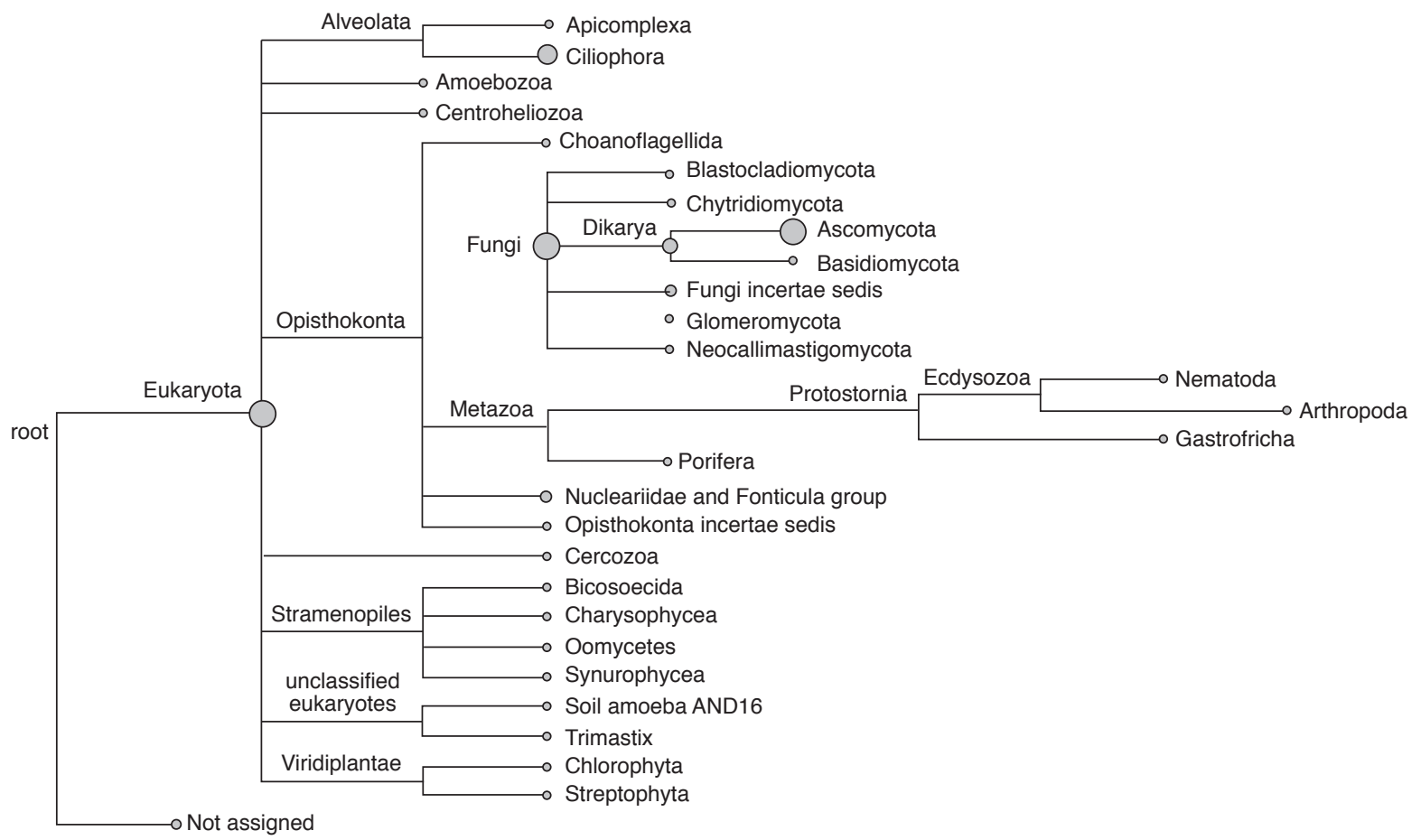

Figure 5b. Phylogeny of eukaryotic phyla at Cermat Ceria (logged-over forest) Sri Aman, Sarawak, Malaysia.

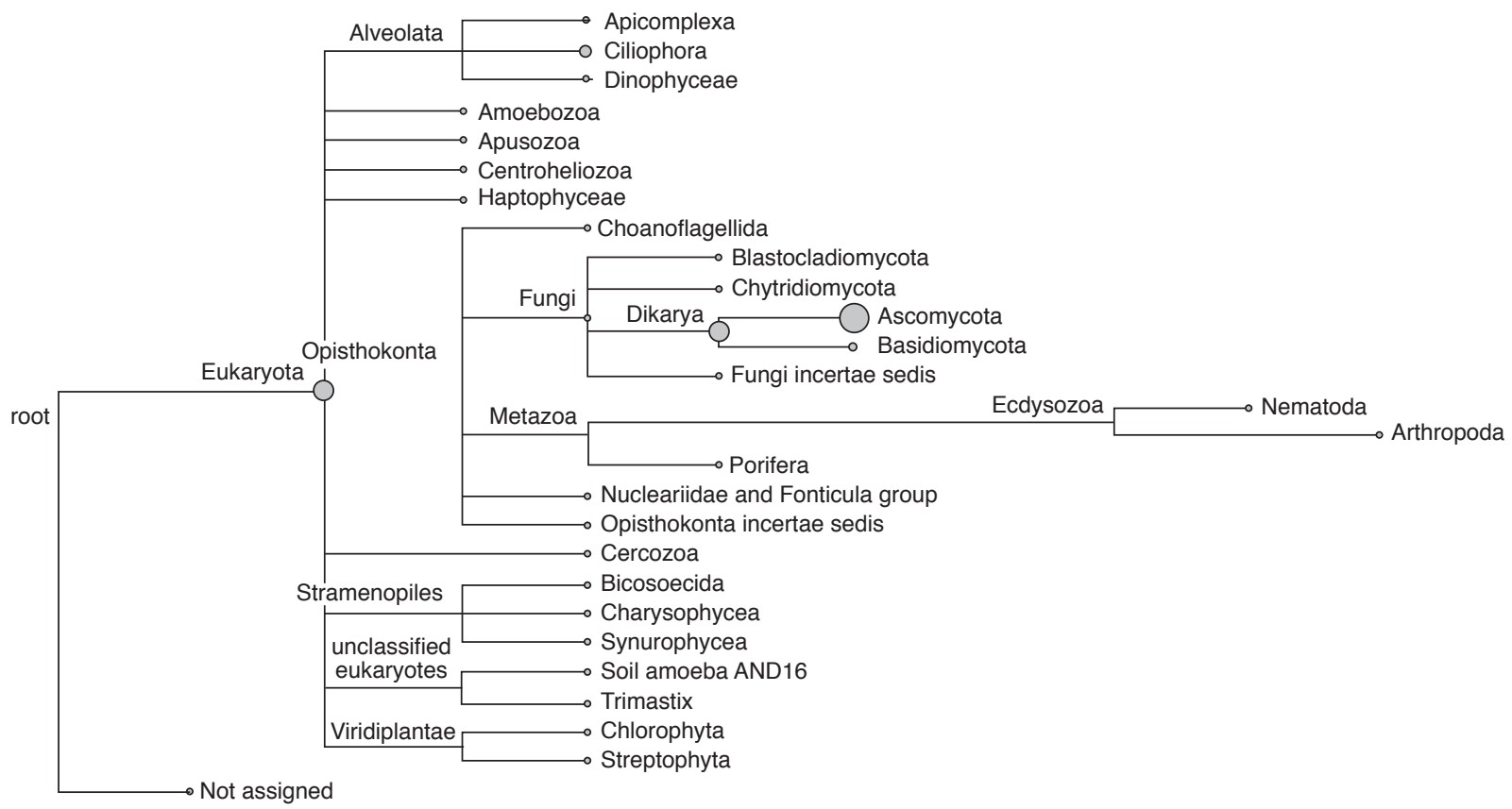

Figure 5c. Phylogeny of eukaryotic phyla under 7 years oil palm at Durafarm, Sri Aman, Sarawak, Malaysia.

et al., 2012). Exploration of the genomes fungi showed that $\mathrm{CDH}$ genes, which appears to be involved in the degradation of both lignin and cellulose (Zhang et al., 2013) were not present in genomes of basal fungi, i.e., Neocallimastigomycota, Blastocladiomycota, Glomeromycota,Kickxellomy cotina, Mucoromycotina, Entomophthoromycotina and Chrytridiomycota (Tangthirasunun et al., 2017).
Neocallimastigomycota detected at Cermat ceria had been isolated from the digestive tracts of over 50 herbivores, including ruminant (Kittelmann et al., 2015) and non-ruminant mammals and herbivorous reptiles (Ljungdahl, 2008) most likely abundant in the logged-over forest as compared to water logged peatland and oil palm cultivated area. 


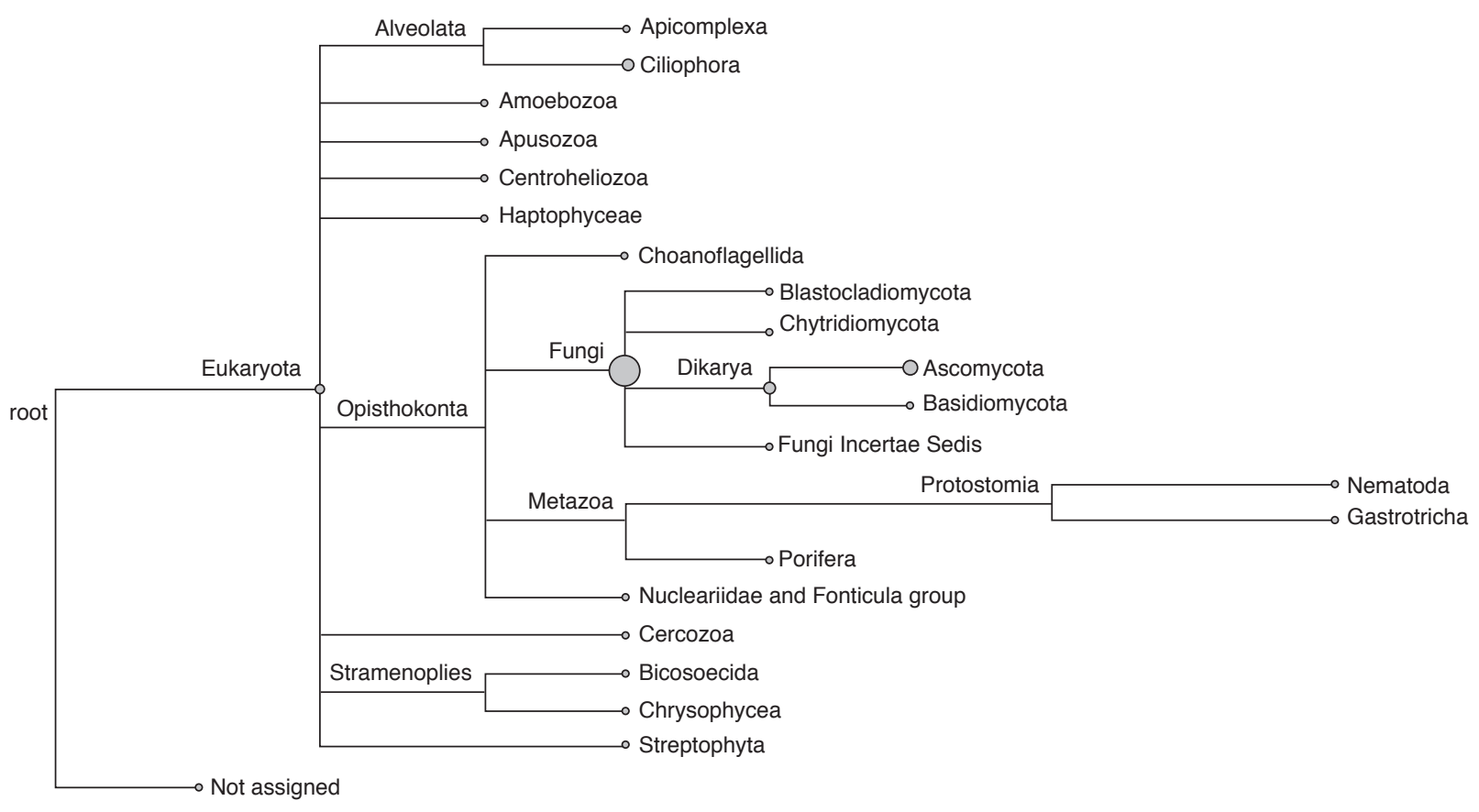

Figure 5d. Phylogeny of eukaryotic phyla under 11 years oil palm at Naman Park Sibu, Sarawak, Malaysia.

\section{Eukaryotic Phylogeny}

The eukaryotic phylogeny for Maludam National Park, logged-over peatland at Cermat Ceria, Oil Palm Plantations at Durafarm and Naman are as seen in Figures $6 a$ to $6 d$. The eukaryotic phylogeny was almost identical for Durafarm (Figure 6c) and Naman (Figure 6d). Like the OTU (Table 3) and $\alpha$-diversity analysis (Figure 2), the total number phylotypes matched with the online database was 100, highest for logged-over mixed peat forest at Cermat Ceria (Figure 6b) followed by 61 for Durafarm (Figure 6c) and Naman (Figure 6d) and 41 or lowest for Maludam (Figure 6a). This implied that the eukaryotic population was most diversified at partially drained logged-over mixed peat forest, followed by oil palm plantations and lowest in the undrained primary mixed peat forest at Maludam, during the dry period in April 2012. The number of identified eukaryotes seem to correspond well with the level of moisture content, which was $204.2 \pm 48.3 \%$ at Cermat Ceria, $181.1 \pm 35.5 \%$ at Durafarm, $139.4 \pm 40.6 \%$ at Naman and lowest $42.3 \pm 8.2 \%$ for peatland at Maludam.

Phylotypes, Sarcocystis under Alveolata is a protozoan genus of parasites found only in Maludam (Figure 6a), infecting muscles and tissues of mammals including human, reptiles, birds, and wildlife species such as deer, moose, elk, caribou, ducks and seals. The oocysts ingested in food or water or through direct contact with faeces can initiate infection in the intestinal epithelia of animals and humans, resulting in morbidity or mortality (Fayer, 1995). Hartmannella, an amoeba predators in microbial food webs (Pickup et al., 2007) was found in oil palm plantations.

Ustilaginomycota was found in peat forest Maludam (Figure 6a) and Cermat Ceria (Figure 6b) but absent in oil palm plantation at Durafarm (Figure 6c) and Naman (Figure 6d) because Ustilaginomycotina or true smut fungi such Ustilago and Tilletia are dicot plant parasites and it is of great economic importance (Begerow et al., 2006) and therefore, obviously not found under monocot oil palm. The Ustilaginomycotina is a subdivision within the division Basidiomycota which has 1400 recognised species in 70 genera. It consists of the classes Ustilaginomycetes and Exobasidiomycetes (Bauer, 1997), and in 2014 the subdivision was reclassified and the two additional classes Malasseziomycetes and Moniliellomycetes (Wang et al., 2014).

\section{CONCLUSION}

Human activities like logging and conversion of peatland for cultivation of oil palm, water management system resulted in physical and chemical changes of peatland ecosystems which led to increased eukaryotic biodiversity as indicated by the high operational taxonomic unit, $\alpha$-diversity and total number phylotypes for logged peatland and oil palm plantations and lowest at peatland at Maludam National Park during dry season. Fungi as determinant of soil fertility was more diversified in oil palm plantations due to high acidity and moisture content with water management system. Dicot parasitic fungi Ustilaginomycota and parasitic 


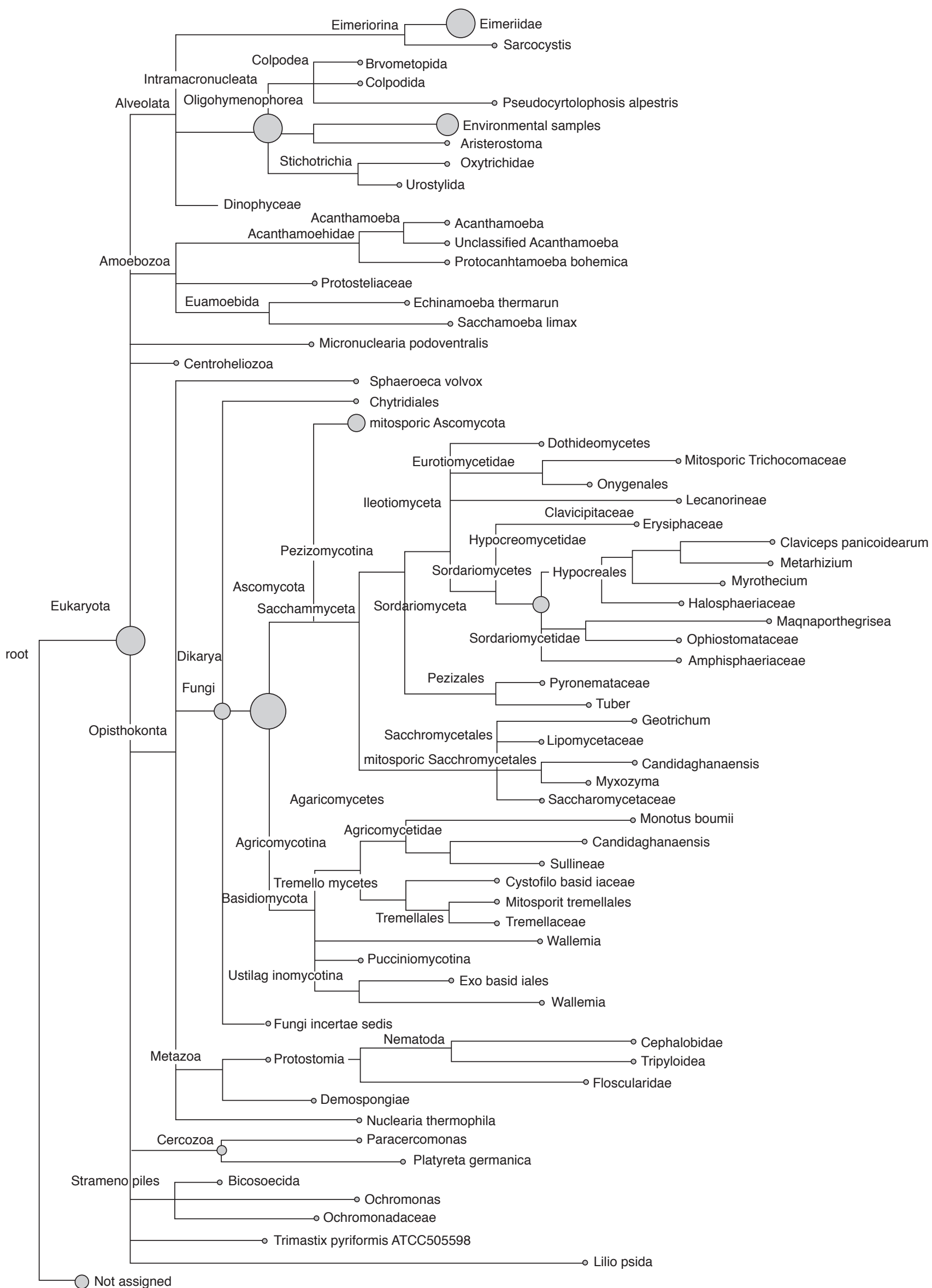

Figure 6a. Eukaryotic phylogeny for Maludam National Park (peatland) at Sri Aman, Sarawak, Malaysia. 


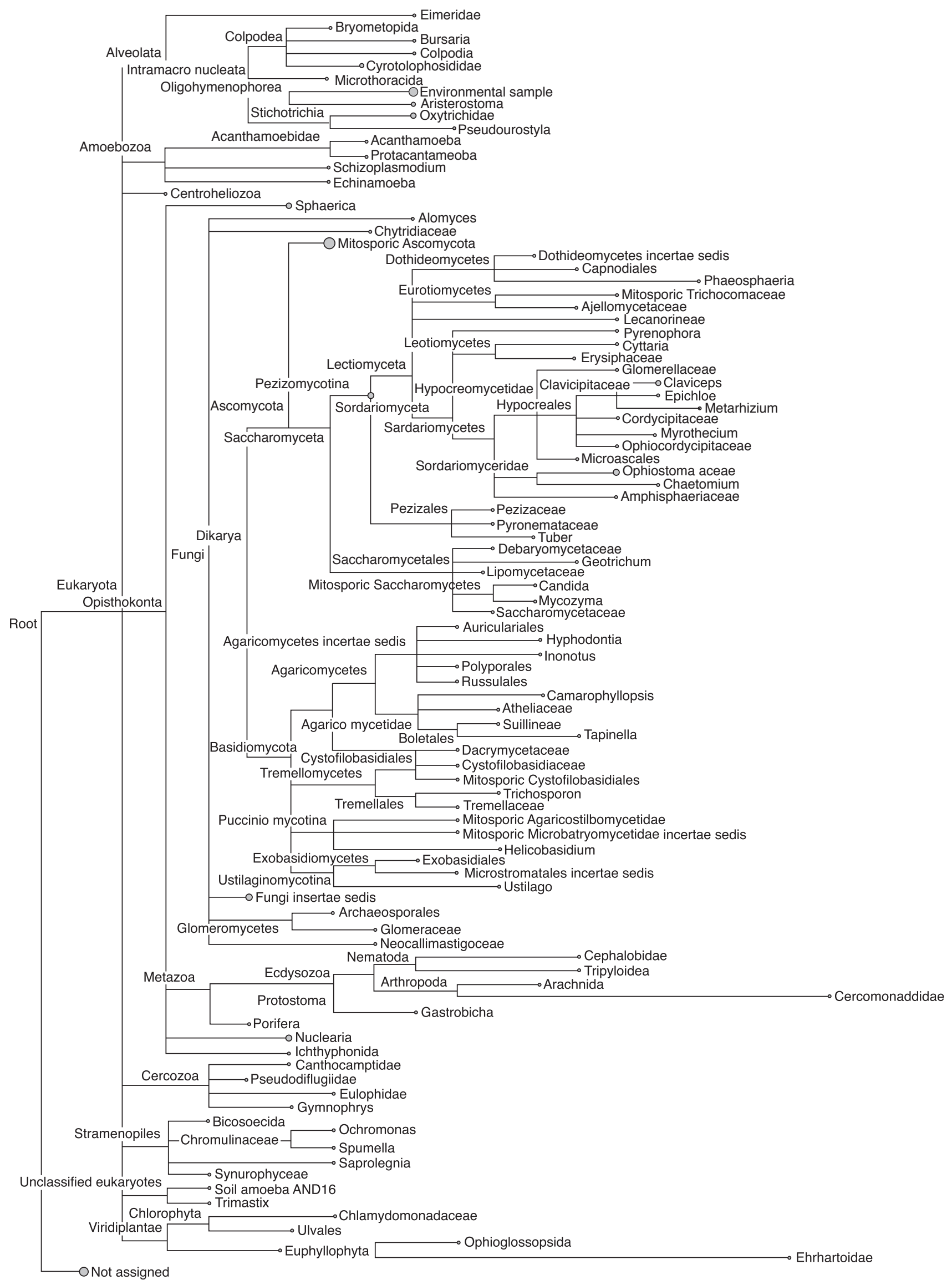

Figure 6b. Eukaryotic phylogeny for logged-over secondary forest Cermat Ceria at Sri Aman, Sarawak, Malaysia. 


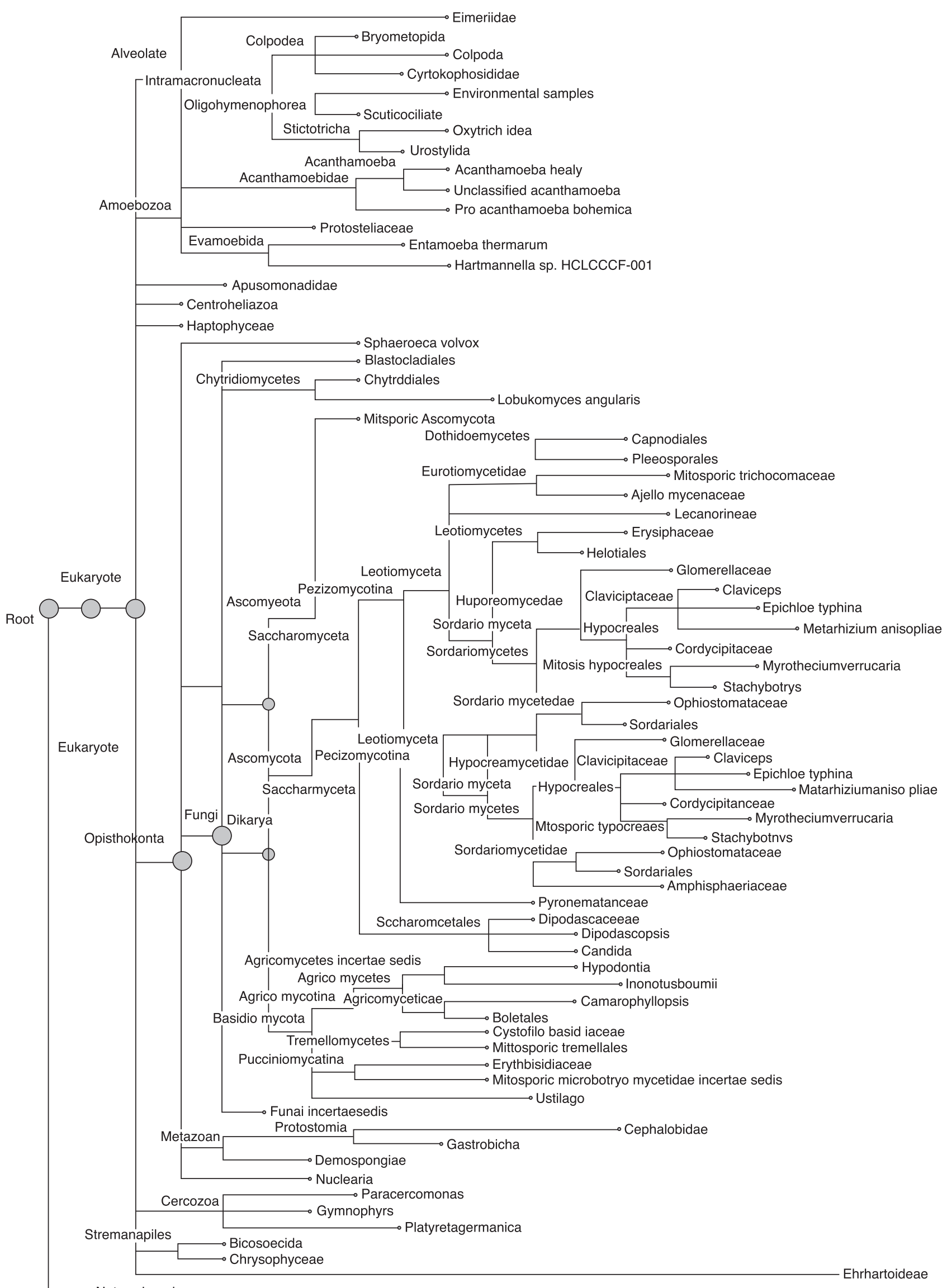

Figure 6c. Eukaryotic phylogeny for 7 years oil palm plantation, Durafarm at Sri Aman, Sarawak, Malaysia. 


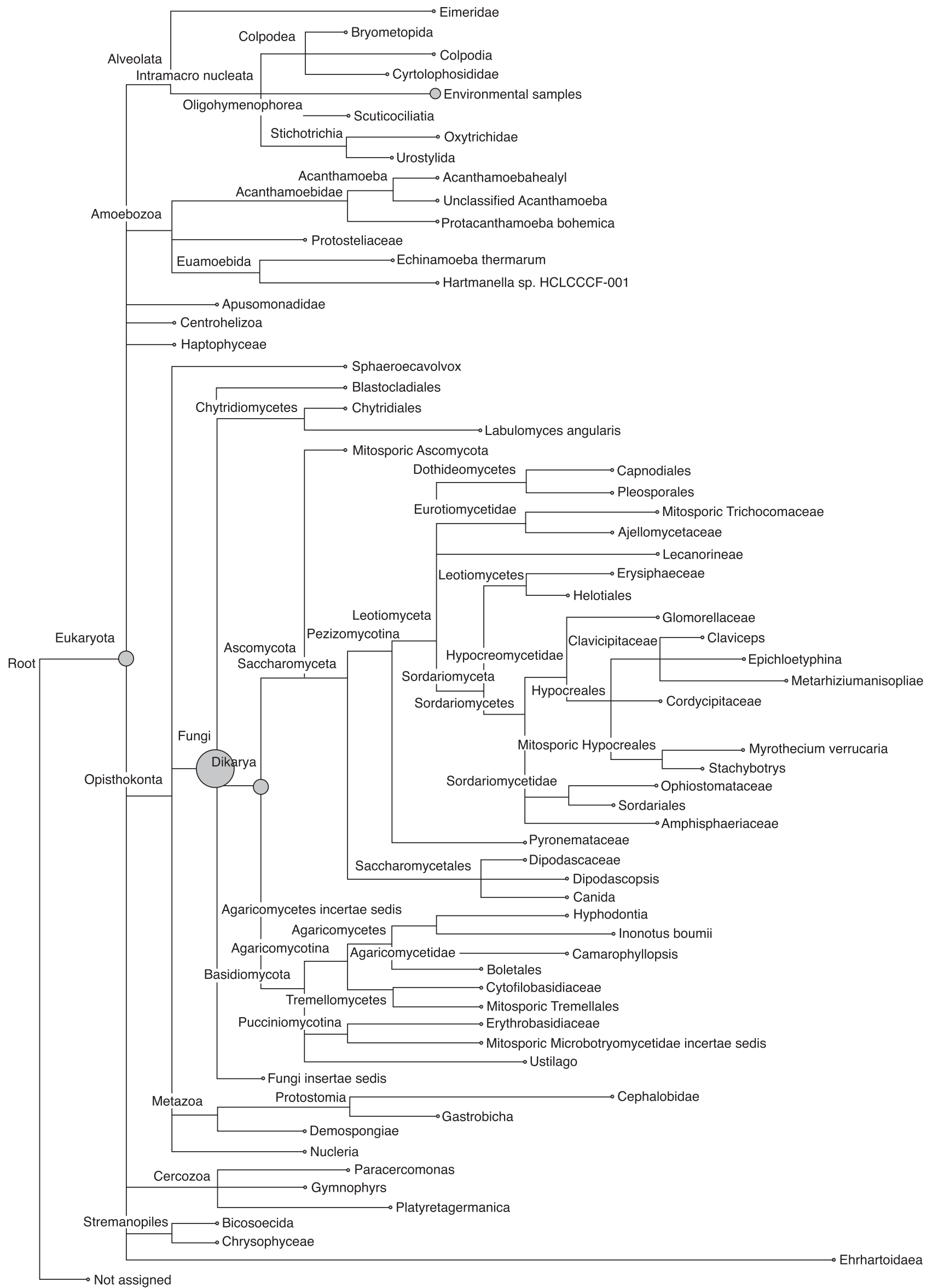

Figure 6d. Eukaryotic phylogeny for 11 years oil palm plantation Naman, Sibu, Sarawak, Malaysia. 
protozoa Sarcocystis were indicators for peatlands and not detected in oil palm plantations.

\section{ACKNOWLEDGEMENT}

The authors would like to thank the DirectorGeneral of MPOB and the Director of Biological Research Division, MPOB for allowing this article to be published. The authors also thank supporting staff of the Soil Microbial Biodiversity and Function Laboratory for their valuable assistance.

\section{REFERENCES}

ADL, S M; SIMPSON, A G; LANE, C E; LUKES, J; BASS, D; BOWSER, S S; BROWN, M W; BURKI, F; DUNTHORN, M; HAMPL, V; HEISS, A; HOPPENRATH, M; LARA, L; GALL, L L; LYNN, D H; MCMANUS, H; MITCHELL, E A; MOZLEYSTANRIDGE, S E; LAURA, W P; PAWLOWSKI, J; RUECKERT, S; SHADWICK, L; SCHOCH, C L; SMIRNOV, A and SPIEGEL, F W (2012). The revised classification of eukaryotes. J. Eukaryotic Microbiology, 59(5): 429-514.

ALEXANDER, T T; TIM, U and SVENNING, M M (2014). Metatranscriptomic analysis of arctic peat soil microbiota. Appl Environ Microbiol. 80(18): 57615772.

ALGUACIL, M D M; TORRES, M P; MONTESINOSNAVARRO, A and ROLDAN, A (2016). Soil characteristics driving arbuscular mycorrhizal fungal communities in semiarid Mediterranean soils. Appl. Environ. Microbiol., 82(11): 3348-3356.

ANDERSEN, R; CHAPMAN, S J and ARTZ, R R E (2013). Microbial communities in natural and disturbed peatlands: A review. Soil Biol. Biochem., 57: 979-994.

BAILLY, J; FRAISSINET-TACHET, L; VERNER, M C; DEBAUD, J C; LEMAIRE, M; WESOLOWSKILOUVEL, $M$ and MARMEISSE, R (2007). Soil eukaryotic functional diversity, a metatranscriptomic approach. The ISME J., 1: 632-642.

BAUER, R; OBERWINKLER, $\mathrm{F}$ and VANKY, $\mathrm{K}$ (1997). Ultrastructural markers and systematics in smut fungi and allied taxa. Can. J. Bot., 75: 1273-1314.

BEGEROW, D; STOL, L M and BAUER, R (2006). A phylogenetic hypothesis of Ustilaginomycotina based on multiple gene analyses and morphological data. Mycologia, 98: 906-916.

BOKULICH, NA and MILLS, D A (2013). Improved selection of internal transcribed spacer-specific primers enables quantitative, ultra-high-throughput profiling of fungal communities. Appl Environ Microbiol., 79: 2519-2526.

CAPORASO, J G; KUCZYNSKI, J; STOMBAUGH, J; BITTINGER, K; BUSHMAN, F D; COSTELLO, E K; FIERER, N; PENA, A G; GOODRICH, J K; GORDON, J I; HUTTLEY, J A; KELLEY, S T; KNIGHTS, D; KOENIG, J E; LEY, R E; LOZUPONE, C A; MCDONALD, D; MUEGGE, B D; PIRRUNG, M; REEDER, J; SEVINSKY, J R; TURNBAUGH, P J; WALTERS, W A; WIDMANN, J; YATSUNENKO, T; ZANEVELD, J and KNIGHT, R (2010). QIIME allows analysis of high-throughput community sequencing data. Nature Methods, 7: 335-336.

COUWENBERG, J and FRITZ, C (2012). Towards developing IPCC methane 'emission factors) for peatlands (organic soils). Mires Peat, 10: 1-17.

DEL CAMPO, J and RUIZ-TRILLO, I (2013). Environmental survey meta-analysis reveals hidden diversity among unicellular Opisthokonts. Molecular Biology and Evolution, 30(4): 802-805.

EBERSBERGER， I; DE MATOS SIMOES, R; KUPCZOK, A; GUBE, M; KOTHE, E; VOIGT, $\mathrm{K}$ and VON HAESELER, A (2012). A consistent phylogenetic backbone for the fungi. Molecular Biology and Evolution, 29: 1319-1334.

FAYER, R (1995). Effect of sodium hypochlorite exposure on infectivity of Cryptosporidium paroum oocysts for neonatal BALB/c mice. Appl. Environ. Microbiol., 61(2): 844-846.

FIERER, N; LAUBER, C L; RAMIREZ, $\mathrm{K}$ S; ZANEVELD, J; BRADFORD, M A and KNIGHT, R (2011). Comparative metagenomics, phylogenetic and physiological analyses of soil microbial communities across nitrogen gradients. ISME J., 6(5): 1007-1017.

FIERER, N; BREITBART, M; NULTON, J; SALAMON, $\mathrm{P}$ and LOZUPONE, C (2007). Metagenomics and small-subunit rRNA analyses reveal the genetic diversity of bacteria, archaea, fungi, and viruses in soil. Appl Environ Microbiol., 73: 7059-7066.

GUILLOU, L; BACHAR, D; AUDIC, S; BASS, D; BERNEY, C; BITTNER, L; BOUTTE, C; BURGAUD, G; DE VARGAS, C; DECELLE, J; DEL CAMPO, J; DOLAN, J R; DUNTHORN, M; DVARDSEN, B; HOLZMANN, M; KOOISTRA, W H C F; LARA, E; LE BESCOT, N; LOGARES, R; MAHE, F; MASSANA, R; MONTRESOR, M; MORARD, R; NOT, F; PAWLOWSKI, J; PROBERT, I; SAUVADET, A L; SIANO, R; STOECK, T; VAULOT, D; 
ZIMMERMANN, P and CHRISTEN, R (2013). The protist ribosomal reference database (PR2): A catalog of unicellular eukaryote small subunit rRNA sequences with curated taxonomy. Nucleic Acids Res. 41: 597-604.

HOOIJER, A; PAGE, S; JAUHIAINEN, J; LEE, W A; LU, X X; IDRIS, A and ANSHARI, G (2012). Subsidence and carbon loss in drained tropical peatlands. Biogeosciences, 9: 1-19.

IHRMARK, K;BÖDEKER, I TM; CRUZ-MARTINEZ, K; FRIBERG, H; KUBARTOVA, A; SCHENCK, J; STRID, Y; STENLID, J; BRANDSTRÖM-DURLING, M; CLEMMENSEN, K E and LINDAHL, B D (2012). New primers to amplify the fungal TS2 region - Evaluation by 454-sequencing of artificial and natural communities. FEMS Microbiol Ecol., 82: 666677.

KITTELMANN, S; MICHELLE, R; JONKER, K A; MCCULLOCH, A and JANSSEN, P H (2015). Buccal swabbing as a non-invasive method to determine bacterial, archaeal, and eukaryotic microbial community structures in the rumen. Appl. Environ. Microbiol., 81: 21-14.

KIP, N; VAN WINDEN, J F; PAN, Y; BODROSSY, L; REICHART, G J; SMOLDERS, A G P; JETTEN, M $S$ M; DAMSTE, J S S and OP DEN CAMP, H J M (2010). Global prevalence of methane oxidation by symbiotic bacteria in peat-moss ecosystems. Nature Geoscience, 3: 617-621.

LAINE, J; VASANDER, $\mathrm{H}$ and SALLANTAUS, $\mathrm{T}$ (1995). Ecological effects of peatland drainage for forestry. Environ. Rev., 3: 286-303.

LIM, K H; LIM, S S; PARISH, F and SUHARTO, R (2012). RSPO Manual on Best Management Practices (BMPs) for Existing Oil Palm Cultivation on Peat. RSPO Secretariat Sdn Bhd, Kuala Lumpur, Malaysia. $214 \mathrm{pp}$.

LJUNGDAHL, L G (2008). The cellulase/ hemicellulase system of the anaerobic fungus Orpinomyces PC-2 and aspects of its applied use. Ann. N. Y. Acad. Sci., 1125: 308-321.

MAC NALLY, R; FLEISHMAN, E; BULLUCK, L $P$ and BETRUS, C J (2004). Comparative influence of spatial scale on beta diversity within regional assemblages of birds and butterflies. J. Biogeography, 31: 917-929.

MONTAGNES, D; ROBERTS, E; LUKES, J and LOWE, C (2012). The rise of model protozoa. Trends Microbiol, 20: 184-191.
MYERS, B; WEBSTER, K L; MCLAUGHLIN, J W and BASILIKO, N (2012). Microbial activity across a boreal peatland nutrient gradient: The role of fungi and bacteria. Wetlands Ecol. Manage., 20: 77-88.

NACKE, $\mathrm{H}$; THURMER, A; WOLLHERR, A; WILL, C; HODAC, L; HEROLD, N; SCHONING, I; SCHRUMPF, $\mathrm{M}$ and DANIEL, $\mathrm{R}$ (2011). Pyrosequencing-based assessment of bacterial community structure along different management types in German forest and grassland soils. PLoS ONE, 6: e17000.

PAGE, S E; WUST, R and BANKS, C (2010). Past and Present Carbon Accumulation and Loss in Southeast Asian Peatlands. Science Highlights: Peatlands. Vol. 18.

PICKUP, Z L; PICKUP, R and PARRY, J D (2007). Effects of bacterial prey species and their concentration on growth of the amoebae Acanthamoeba castellanii and Hartmannella vermiformis. Appl. Environ. Microbiol., 73(8): 2631-2634.

QUAST, C; PRUESSE, E; YILMAZ, P; GERKEN, J; SCHWEER, T; YARZA, P; PEPLIES, J and GLOCKNER, F (2013). The SILVA ribosomal RNA gene database project: Improved data processing and web-based tools. Nucl. Acids Res., 41 (D1): D590-D596.

RILEY, J L (2011). Wetlands of the Hudson Bay Lowland: An Ontario Overview. Nature Conservancy of Canada, Toronto, ON. 156 pp.

SITI RAMLAH, A A; SAKINAH, S; SHAWAL, M T; SHAMSILAWANI, A B and NUR AZIEMAH, A G (2016). Soil fungal community associated with peat in Sarawak identified using $18 \mathrm{~S}$ rDNA marker. J. Oil Palm Res. Vol. 28(2): 161-171.

STRAKOVA, P; PENTTILA, T; LAINE, J and LAIHO, $R$ (2012). Disentangling direct and indirect effects of water table drawdown on above- and below-ground plant litter decomposition: Consequences for accumulation of organic matter in boreal peatlands. Global Change Biol., 18(1): 322-335.

SMIT, E; LEEFLANG, P; GLANDORF, B and DIRK, J AN (1999). Analysis of fungal diversity in the wheat rhizosphere by sequencing of cloned PCR-amplified genes encoding 18S rRNA and temperature gradient gel electrophoresis. Appl. Environ. Microbiol., 65: 2614-2621.

SEUTHE, L; IVERSEN, $\mathrm{K} \mathrm{R}$ and NARCY, $\mathrm{F}$ (2011). Microbial processes in a high-latitude fjord (Kongsfjorden, Svalbard). II. Ciliates and dinoflagellates. Polar Biol., 34: 751-766. 
TAKASHI, H; KITSO, K; SUWIDO, H L and OSAKI, M (2014). Carbon dioxide emissions through oxidative peat decomposition on a burnt tropical peatland. Global Change Biology, 20(2): 555-565.

TANGTHIRASUNUN, $\mathrm{N}$; NAVARRO, D; GARAJOVA, S; CHEVRET, D; TONG, L C H; GAUTIER, V; HYDE, K D; SILAR, P and BERRIN, J $G$ (2017). Inactivation of cellobiose dehydrogenases modifies the cellulose degradation mechanism of Podospora anserine. Applied and Environmental Microbiology, 83(2): 1-13.

TAYLOR, D L; HOLLINGSWORTH, T N; MCFARLAND, J W; LENNON, N J; NUSBAUM, C and RUESS, R W (2014). A first comprehensive census of fungi in soil reveals both hyperdiversity and fine-scale niche partitioning. Ecology Monogr., 84:3-20.

TAYLOR, D L and SINSABAUGH, R L (2014). The soil fungi: Occurrence, phylogeny, and ecology. Soil Microbiology, Ecology and Biochemistry (Paul, E A ed.). $4^{\text {th }}$ ed. Academic Press, Burlington, MA. p. 77.

TAYLOR, D L; WALTERS, W A; LENNON, N J; JBOCHICCHIO, J; KROHN, A; CAPORASO, A J and PENNANENE, T (2016). Accurate estimation of fungal diversity and abundance through improved lineage-specific primers optimized for Illumina amplicon sequencing. Appl. Environ. Microbiol., 82(24): 7217-7226.

TEDERSOO, L; ANSLAN, S; BAHRAM, M; POLME, S; RIIT, T; LIIV, I; KOLJALG, U; KISAND, V; NILSSON, R; HILDEBRAND, F; BORK, P and ABARENKOV, K (2015). Shotgun metagenomes and multiple primer pair-barcode combinations of amplicons reveal biases in metabarcoding analyses of fungi. MycoKeys, 10: 1-43.

THORMANN, M (2011). In vitro decomposition of Sphagnum-derived acrotelm and mesotelm peat by indigenous and alien basidiomycetous fungi. Mires Peat, 8(3): 1-12.

TORRUELLA, G; DERELLE, R; PAPS, J; FRANZ LANG, B; ROGER, A J; SHALCHIAN-TABRIZI, K and AKI RUIZ-TRILLO, I (2012). Phylogenetic relationships within the Opisthokonta based on phylogenomic analyses of conserved single-copy protein domains. Molecular Biology and Evolution, 29 (2): 531-544.

TU, Q; YUAN, M; HE, Z; DENG, Y; XUE, K; WU, L; HOBBIE, S E; REICH, P B and ZHOU, J (2015). Fungal communities respond to long-term $\mathrm{CO}_{2}$ elevation by community reassembly. Appl. Environ. Microbiol, 81(7): 2445-2454

TVEIT, A T; URICH, T and SVENNING, M M (2014). Meta transcriptomic analysis of Artic peat soil microbiota. Applied and Environmental Microbiology, 80(18): 5761-5772.

URICH, T; LANZEN, A; QI, J; HUSON, D H and SCHLEPER, C (2008). Simultaneous assessment of soil microbial community structure and function through analysis of the meta-transcriptome. PLoS ONE, 3(6): e2527. DOI:10.1371/ journal.pone.0002527

VAN DER HEIJDEN, M G A; BARDGETT, R D and VAN STRAALEN, N M (2008). The unseen majority: soil microbes as drivers of plant diversity and productivity in terrestrial ecosystems. Ecol. Lett., 11: 296-310.

WANG, Q W; BEGEROW, D; GROENEWALD, M; LIU, X Z; THEELEN, T; BAI, F Y and BOEKHOUT, $\mathrm{T}$ (2014). Multigene phylogeny and taxonomic revision of yeasts and related fungi in the Ustilaginomycotina. Studies in Mycology, 81: 55-83.

WINSBOROUGH, C and BASILIKO, N (2010). Fungal and bacterial activity in northern peatlands. Geomicrobiol. J., 27: 315-320.

YUANYUAN, L; LONGQIAN, C; HONGYU, W; TIANJIAN, Z; TING, Z and XIAL, G (2014). 454 Pyrosequencing analysis of bacterial diversity revealed by a comparative study of soils from mining subsidence and reclamation areas. J. Microbiol. Biotechnol., 24(3): 313-323.

YU, Z C (2012). Northern peatland carbon stocks and dynamics: A review. Biogeosciences, 9: 4071- 4085.

ZHANG, R; XU, C; SHEN, Q; KASUGA, T; WU, W; SZEWCZYK, E; MA, D and FAN, Z (2013). Characterization of two cellobiose dehydrogenases and comparison of their contributions to total activity in Neurospora crassa. Int Biodeterior Biodegradation, 82: 24-32. 